\title{
Social Media and the Public Sphere
}

\author{
Christian Fuchs
}

\author{
University of Westminster, London, UK, christian.fuchs@uti.at, http://fuchs.uti.at
}

\begin{abstract}
Social media has become a key term in Media and Communication Studies and public discourse for characterising platforms such as Facebook, Twitter, YouTube, Wikipedia, Linkedln, Wordpress, Blogspot, Weibo, Pinterest, Foursquare and Tumblr. This paper discusses the role of the concept of the public sphere for understanding social media critically. It argues against an idealistic interpretation of Habermas and for a cultural-materialist understanding of the public sphere concept that is grounded in political economy. It sets out that Habermas' original notion should best be understood as a method of immanent critique that critically scrutinises limits of the media and culture grounded in power relations and political economy. The paper introduces a theoretical model of public service media that it uses as foundation for identifying three antagonisms of the contemporary social media sphere in the realms of the economy, the state and civil society. It concludes that these limits can only be overcome if the colonisation of the social media lifeworld is countered politically so that social media and the Internet become public service and commons-based media.
\end{abstract}

Keywords: social media, Internet, public sphere, Jürgen Habermas, political economy, public service media

Acknowledgement: This paper is the extended printed version of Christian Fuchs' inaugural lecture for his professorship of social media at the University of Westminster that he took up on February $1^{\text {st }}, 2013$. He gave the lecture on February $19^{\text {th }}, 2014$, at the University of Westminster.

\section{Introduction}

Contributions to discussions of Internet, social media and the public sphere often tend to stress new technologies' transformative power. Some examples:

- Yochai Benkler stresses the emergence of a networked public sphere: "The easy possibility of communicating effectively into the public sphere allows individuals to reorient themselves from passive readers and listeners to potential speakers and participants in a conversation" (Benkler 2006, 213). "The network allows all citizens to change their relationship to the public sphere. They no longer need be consumers and passive spectators. They can become creators and primary subjects. It is in this sense that the Internet democratizes" (Benkler 2006, 272)

- Zizi Papacharissi describes the emergence of a "virtual sphere 2.0", in which citizenconsumers participate and express "dissent with a public agenda [...] by expressing political opinion on blogs, viewing or posting content on YouTube, or posting a comment in an online discussion group" (Papacharissi 2009, 244).

- Manuel Castells stresses the novelty of this sphere: "The construction of the new public sphere in the network society proceeds by building protocols of communication between different communication processes" (Castells 2009, 125).

- Jean Burgess and Joshua Green $(2009,77)$ argue that YouTube is a "cultural public sphere" because "it is an enabler of encounters with cultural differences and the development of political 'listening' across belief systems and identities".

Such contributions differ in how much they stress networking, dissent, novelty and culture, but have in common that they are philosophically idealistic interpretations or revisions of $\mathrm{Ha}$ bermas' concept of the public sphere. They focus on political and cultural communication and ignore the public sphere's materiality and political economy that Habermas stressed. Consequently, they do not ask questions about ownership and do not see, as Nicholas Garnham 
stresses, that besides the focus on political communication a "virtue of Habermas's approach is to focus on the necessary material resource base for any public sphere" (Garnham 1992, 361). Habermas points out that the public sphere is a question of its members' command of resources (property, intellectual skills) "But even under ideally favorable conditions of communication, one could have expected from economically dependent masses a contribution to the spontaneous formation of opinion and will only to the extent to which they had attained the equivalent of the social independence of private property owners" (Habermas 1992, 434). The approaches discussed above do not ask the questions: Who owns Internet platforms? Who owns social media?

The contribution presented in this paper challenges public sphere idealism. It argues for a materialistic understanding and return to Habermas' original concept that encompasses the perspective of critical political economy as a foundation for the analysis of so-called "social media". Social media has since the mid-2000s become a buzzword and marketing ideology aimed at attracting users and investors to platforms such as Facebook, Twitter, YouTube, Wikipedia, LinkedIn, VKontakte, Blogspot, Weibo, Wordpress, Tumblr, Pinterest, or Instagram. Many people understand social networking sites, blogs, wikis, user-generated content sharing sites and microblogs as social media. The term social media however brings up the question if not all media are in one respect or another social. This depends on how one defines the social. As a consequence, one needs social theory in order to understand what is social about social media (Fuchs 2014c).

Sociality can mean that a) human thought is shaped by society, b) humans exchange symbols by communicating in social relations, c) humans work together and thereby create use-values, d) humans form and maintain communities. These definitions of sociality correspond to the social theory concepts of social facts, social relations, co-operation and community (Fuchs 2014c, chapter 2). Described as information processes, sociality can be expressed as a threefold interconnected process of cognition (a), communication (b) and cooperation (c, d) (Fuchs 2014c, chapter 2). Media and online platforms reflect these forms of sociality to different degrees:

- Cognition: Reading books, watching the news or a film on TV and listening to the radio involves just like Internet use the engagement with texts that reflect social contexts in society.

- Communication: Online communication is not new: Ray Tomlinson sent the first Internet email from one computer to the other in $1971^{1}$.

- Co-operation: Online communities are not new, already in the 1980s there were bulletin board systems such as the WELL. Computer-supported co-operative work (CSCW) became an academic field of studies in the 1980s, reflecting the role of the computer in collaborative work. The 1st ACM Conference on CSCW took place in December 1986 in Austin, Texas. The concept of the wiki is also not new: Ward Cunningham introduced the first wiki technology (the WikiWikiWeb) in 1995.

Online sociality is not new. A specific aspect of Facebook and related platforms is that they integrate tools that support various forms of sociality into one platform. They are tools of cognition, communication and co-operation. How has the landscape of the World Wide Web (WWW) changed in the past 10 years? Table 1 presents an analysis of the most used websites in the world in 2002 and 2013.

\footnotetext{
${ }^{1}$ See http://openmap.bbn.com/ tomlinso/ray/firstemailframe.html and http://openmap.bbn.com/ tomlinso/ray/ka10.html
} 


\begin{tabular}{|c|c|c|c|c|c|}
\hline \multicolumn{3}{|c|}{$\begin{array}{c}\text { December } 9^{\text {th }} 2002 \text { (three month page } \\
\text { ranking based on page views and page } \\
\text { reach) }\end{array}$} & \multicolumn{3}{|c|}{$\begin{array}{l}\text { December } 11 \mathrm{t}^{\mathrm{h}}, 2013 \text { (one month page ranking } \\
\text { based on average daily visitors and page views) }\end{array}$} \\
\hline Rank & Website & $\begin{array}{c}\text { Primary } \\
\text { information } \\
\text { functions }\end{array}$ & Rank & Website & $\begin{array}{l}\text { Primary information } \\
\text { functions }\end{array}$ \\
\hline 1 & yahoo.com & cogn, comm & 1 & google.com & cogn, comm, coop \\
\hline 2 & msn.com & cogn, comm & 2 & facebook.com & cogn, comm, cop \\
\hline 3 & daum.net & cogn, comm & 3 & youtube.com & cogn, comm \\
\hline 4 & naver.com & cogn, comm & 4 & yahoo.com & cogn, comm \\
\hline 5 & google.com ${ }^{2}$ & $\operatorname{cogn}$ & 5 & baidu.com & cogn, comm \\
\hline 6 & yahoo.co.jp & cogn, comm & 6 & wikipedia.org & cogn, comm, coop \\
\hline 7 & passport.net & $\operatorname{cog} n$ & 7 & qq.com & cogn, comm \\
\hline 8 & ebay.com & $\operatorname{cog} n$ & 8 & amazon.com & cogn \\
\hline 9 & microsoft.com & $\operatorname{cog} n$ & 9 & live.com & cogn, comm \\
\hline 10 & bugsmusic.co.kr & $\operatorname{cog} n$ & 10 & taobao.com & $\operatorname{cogn}$ \\
\hline 11 & sayclub.com & cogn, comm & 11 & twitter.com & cogn, comm \\
\hline 12 & sina.com.cn & cogn, comm & 12 & linkedin.com & cogn, comm, coop \\
\hline 13 & netmarble.net & $\begin{array}{l}\text { cogn, comm, } \\
\text { coop }\end{array}$ & 13 & blogspot.com & cogn, comm \\
\hline 14 & amazon.com & $\operatorname{cog} n$ & 14 & google.co.in & cogn, comm, coop \\
\hline 15 & nate.com & cogn, comm & 15 & sina.com.cn & cogn, comm \\
\hline 16 & go.com & $\operatorname{cog} n$ & 16 & hao123.com & $\operatorname{cogn}$ \\
\hline 17 & sohu.com & cogn, comm & 17 & 163.com & cogn, comm \\
\hline 18 & 163.com & cogn, comm & 18 & wordpress.com & cogn, comm \\
\hline 19 & hotmail.com & cogn, comm & 19 & ebay.com & $\operatorname{cog} n$ \\
\hline 20 & aol.com & cogn, comm & 20 & yahoo.co.jp & cogn, comm \\
\hline & & $\begin{array}{l}\text { cogn: } 20 \\
\text { comm: } 13 \\
\text { coop: } 1\end{array}$ & & & $\begin{array}{l}\text { cogn: } 20 \\
\text { comm: } 15 \\
\text { coop: } 5\end{array}$ \\
\hline
\end{tabular}

Table 1: Information functions of the top 20 websites in the world (data source: alexa.com)

In 2002, there were 20 information functions and 13 communication functions and one cooperation function available on the top 20 websites. In 2013, there were 20 information functions, 15 communication functions, and 5 cooperation functions on the top 20 websites. The quantitative increase of collaborative features from 1 to 5 has to do with the rise of Facebook, Google+, Wikipedia and Linkedln: collaborative information production with the help of wikis and collaborative software (Wikipedia, Google Docs) and social networking sites oriented on community-building (Facebook, Google+, Linkedln). There are continuities and discontinuities in the development of the WWW in in the period 2002-2013. The changes concern the rising importance of co-operative sociality. This change is significant, but not dramatic. One novelty is the rise of social networking sites (Facebook, Linkedln, Google+, MySpace, etc). Another change is the emergence of blogs (Wordpress, Blogger/Blogpost, Huffington Post), microblogs (Twitter) and file sharing web sites (YouTube), which have increased the possibilities of communication and information sharing in the top 20 US websites. Google has broadened its functions: It started as a pure search engine (in 1999), introduced communication features in 2007 (gMail) and its own social networking site platform (Google+) in June 2011.

This paper contextualizes social media in society with the help of the concept of the public sphere. The public sphere is just one way of achieving this aim, there are other social theory

\footnotetext{
${ }^{2}$ Google's main communicative feature, the email service gMail, was launched in 2004.
} 
concepts (such as power, ideology, capitalism, democracy, participation, labour, control, surveillance) that need to be used together with the notion of the public sphere in a theory of the Internet and society (Fuchs 2008, 2014c). Section 2 discusses the concept of the public sphere, section 3 the role of the media in the public sphere, section 4 social media and the public sphere. Section 5 draws some conclusions about how to advance from social media as a sphere colonised by capital and the state towards social media as public service, commons-based media and a truly public sphere.

\section{The Concept of the Public Sphere}

Habermas $(1991,1)$ stresses that if something is public it is "open to all". The task of a public sphere is that society can become engaged in "critical public debate" (Habermas 1991, 52). The public sphere would therefore require media for information and communication and access by all citizens. The logic of the public sphere is independent of economic and political power (Habermas 1991, 36): "Laws of the market [...] [are] suspended as were laws of the state". Habermas thereby stresses that the public sphere is not just a sphere of public political communication, but also a sphere free from state censorship and from private ownership. It is free from particularistic controls.

Both Jürgen Habermas (1991) and Hannah Arendt (1958) stress that in pre-modern society the private realm was simultaneously the realm of the family and the economy. Modern society would have seen the rise of the capitalist economy and the modern state as relatively autonomous interconnected spheres. The economy became disembedded from the family and a separate sphere of modern society based on commodity production and wage-labour emerged. The realm of the economy is mediated with the household as realm of reproductive labour. "The emergence of society - the rise of housekeeping, its activities, problems, and organizational devices - from the shadowy interior of the household into the light of the public sphere, has not only blurred the old borderline between private and political, it has also changed almost beyond recognition the meaning of the two terms and their significance for the life of the individual and the citizen" (Arendt 1958, 38). The notion of the private became split into the sphere of private ownership in the economy and intimacy in the family. The economy started to no longer be part of private households, but became organised with the help of large commodity markets that go beyond single households. The modern economy became "a private sphere of society that [...] [is] publicly relevant" (Habermas 1989, 19). It became a political economy. The British economist James Steuart formulated this change in 1767 in his book An inquiry into the principles of political economy - that was the first English book having the term "political economy" in its title - the following way: "What oeconomy is in a family, political oeconomy is in a state" (Steuart 1767). Political economy also became a field of study that analyses the production, distribution and consumption of goods and considered the moral question of how the state and the economy shall best be related (Caporaso and Levine 1992).

The question that arises is how the public sphere that is sometimes also related to the concept of civil society is related to other realms of modern societies. Habermas (1987, 1991, 2006) has stressed in many of his works that it is a kind of interface and intermediate sphere mediating between the economy, the state, and the realm of the family and intimacy. The "public sphere is a warning system with sensors that, though unspecialized, are sensitive throughout society" (Habermas 1996, 359). Modern society can be conceived as consisting of distinct and connected spheres: the economy is the sphere of the production of usevalues, politics the sphere where collective decisions are taken, and culture the sphere where social meanings and moral values are created (Fuchs 2008). In modern society, these spheres are based on the accumulation of money, power and status (Fuchs 2008). In Habermas' $(1984,1987)$ theory, this distinction is reflected in his differentiation between the systems of the economy and politics and the lifeworld. He however assumes that the cultural lifeworld is not shaped by power asymmetries, whereas in capitalist realities contemporary culture tends to be, as Pierre Bourdieu (1984) stresses, a struggle over recognition and status. The public sphere/civil society connects culture, the economy and politics and thereby 
creates sections of overlap between the public sphere and these realms: the socio-political sphere, the socio-economic sphere and the socio-cultural sphere.

Figure 1 visualizes a model of modern society. The model is grounded in the social theory insight that the relationship between structures and actors is dialectical and that both levels continuously create each other (for dialectical solutions of the structure-agency problem in social theory, see: Archer 1995, Bhaskar 1993, Bourdieu 1986, Fuchs 2003a, 2003b, Giddens 1984).

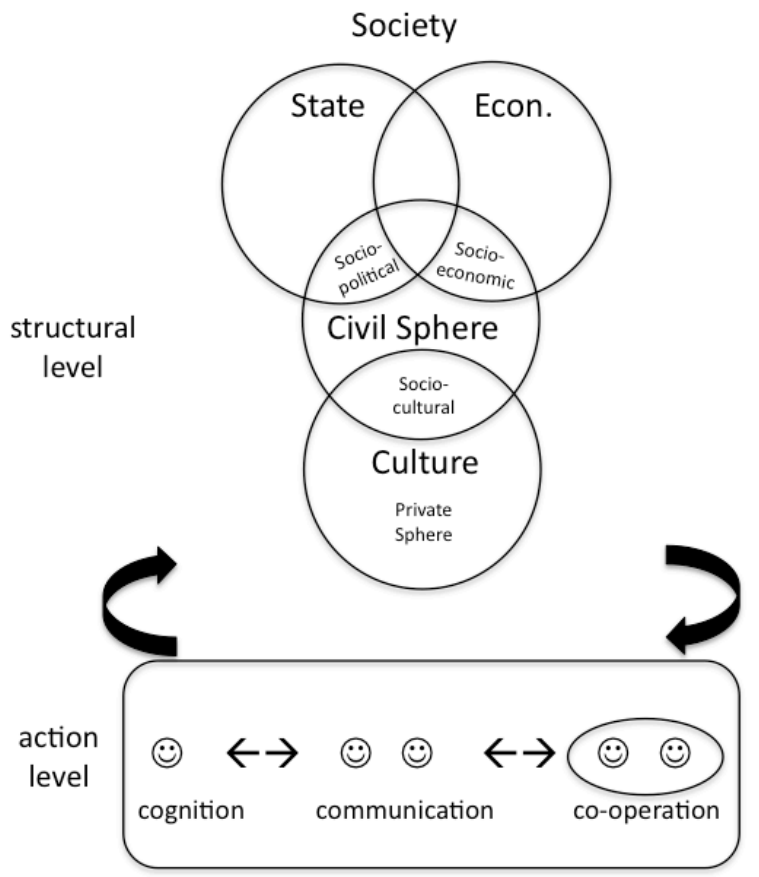

Figure 1: A model of modern society

Habermas $(1987,320)$ mentions the following social roles that are constitutive for modern society: employee, consumer, client, citizen. Other roles, as e.g. wife, husband, houseworker, immigrant, convicts, etc can certainly be added. So what is constitutive for modern society is not just the separation of spheres and roles, but also the creation of power structures, in which roles are constituted by and connected to power relations (as e.g. employer-employee, state bureaucracy-citizen, citizen of a nation state-immigrant, manager-assistant, dominant gender roles - marginalised gender roles). Power means in this context the disposition of actors over means that allow them to control structures, influence processes and decisions in their own interest. In the modern economy, humans act as capital owners or workers. In the modern political system, they act as politicians or citizens. In the modern cultural system, they have the roles of friends, lovers, family members and consumers. Modern society is not just based on a differentiation of social realms, but also a differentiation of social roles humans take on in these realms. In the public realm, humans do not act in isolation, but in common. For Hannah Arendt, the public sphere is therefore "the common world" that "gathers us together and yet prevents our falling over each other" (Arendt 1958, 52). In the public sphere, humans organise around specific interests as social groups. As groups they take on socio-economic, socio-political and socio-cultural roles. Table 2 shows an overview of these roles in modern society. As modern society is based on structures of accumulation and a separation of roles within different realms, there are conflicts of interest over the control of property, collective decisions and meanings that can result in social struggles. Economic, political and cultural roles in modern society are organized in the form of classes, parties and political groups, and communities of interest that compete over the control of property/surplus, collective decision and social meanings. 


\begin{tabular}{|l|l|}
\hline $\begin{array}{l}\text { Political roles } \\
\text { citizen, politician, bureaucrat, politi- } \\
\text { cal party member }\end{array}$ & $\begin{array}{l}\text { Socio-political roles } \\
\text { privacy advocates, electoral reform advocate, } \\
\text { feminist activist, gay-rights activists, anti-racist } \\
\text { advocate, youth movement advocate, peace } \\
\text { movement activist, anti-penitentiary advocate, } \\
\text { anti-psychiatry activist, non-governmental organ- } \\
\text { isation member/activist, non-parliamentary politi- } \\
\text { cal activist (student groups, non-parliamentary } \\
\text { fascist groups, non-parliamentary leftist groups, } \\
\text { etc) }\end{array}$ \\
\hline $\begin{array}{l}\text { Economic roles } \\
\text { capital owner, entrepreneur, man- } \\
\text { ager, employee, prosumer, self- } \\
\text { employee }\end{array}$ & $\begin{array}{l}\text { Socio-economic roles } \\
\text { labour activist, union member, consumer protec- } \\
\text { tionists, environmental activist }\end{array}$ \\
\hline $\begin{array}{l}\text { Private roles } \\
\text { lover, family member, friend, con- } \\
\text { sumer, audience member, user }\end{array}$ & $\begin{array}{l}\text { Socio-cultural roles } \\
\text { sports group member, fan community member, } \\
\text { parishioner, member of a sect or cult, profes- } \\
\text { sional organizations and associations, self-help } \\
\text { groups, neighbourhood association, etc }\end{array}$ \\
\hline
\end{tabular}

Table 2: Social roles in modern society

Peter Lunt and Sonia Livingstone (2013) reflect on articles covering the topic of the public sphere that were published in the years 1979-2012 in the journal Media, Culture \& Society. They say that Habermas faced many criticism, including "his ideal of civic republicanism based on a form of direct democracy that could not accommodate the complexity and scale of modern society" and "his apparent blindness to the many varieties of exclusion (based on gender, class, ethnicity, etc.)" (Lunt and Livingstone 2013, 90). He would have revised his approach, recognising "a plurality of public spheres" and "the contested nature of public life" (Lunt and Livingstone 2013, 92) as well as the "importance of inclusivity, diversity, identity, the end of consensus government, distributed governance, and the complexity of social systems" (95).

Lunt and Livingstone point out doubts that can be summarised as three main criticisms of Habermas' notion of the public sphere:

- The working class critique

- The postmodern critique

- The cultural imperialism critique

The working class critique stresses that Habermas focuses on the bourgeois movement and neglects other popular movements that existed in the $17^{\text {th }}, 18^{\text {th }}$ and $19^{\text {th }}$ century, such as the working class movement. Oskar Negt's and Alexander Kluge's (1993) notion of a proletarian (counter) public sphere can be read as both a socialist critique and a radicalization of Habermas' approach (see: Calhoun 1992, 5; Jameson 1988).

Such criticism should however see that Habermas acknowledged in the preface of Structural Transformation the existence of a "plebeian public sphere" like in the Chartist movement or the anarchist working class (Habermas 1991, xviii) and that he pointed out that the "economically dependent masses" would only be able to contribute "to the spontaneous formation [...] of opinion [...] to the extent to which they had attained the equivalent of the social independence of private property owners" (Habermas 1992, 434).

Edward P. Thompson (1963) describes how Jacobin societies such as the London Corresponding Society fought for working class representation in parliament, met in taverns such as the London Tavern, public houses and public places. The London Corresponding Society (LCS) formed in 1792. Women were not allowed to attend the London debating societies in 
the first 30 years, which changed in the 1770s (Thale 1995). There was a 6 pence entry fee to the LCS meetings, so not everyone could attend. So it clearly was a public sphere with limits. There were around 650 participants at each weekly debate (Thale 1989). There were not just indoor, but also outdoor meetings. The LCS propagated Mary Wollstonecraft's feminist writings.

The working class critique often also argues that Habermas idealises the bourgeois public sphere, which is however a misunderstanding. Habermas does not idealise the bourgeois public sphere, but rather applies an elegant dialectical logic to show that the bourgeois ideals and values find their own limits in the existence of stratified power relations and class. Habermas showed based on Marx (critique of the political economy: class character of the public sphere) and Horkheimer (ideology critique: manipulated public sphere) how the very principles of the public sphere are stylised principles that in reality within capitalist society are not realised due to the exclusory character of the public sphere and the manipulation of the public sphere by particularistic class interests. Habermas' theory of the public sphere is an ideology-critical study in the tradition of Adorno's (2003) method of immanent critique that confronts the ideals of the public sphere with its capitalist reality and thereby uncovers its ideological character. The implication is that a true public sphere can only exist in a participatory society.

Liberal ideology postulates individual freedoms (of speech, opinion, association, assembly) as universal rights, but the particularistic and stratified character of unequal societies undermines these universal rights and creates inequality and therefore unequal access to the public sphere. There are specifically two immanent limits of the bourgeois public sphere that Habermas discusses:

- The limitation of freedom of speech and public opinion: if individuals do not have same formal education and material resources available, then this can pose limits for participation in the public sphere (Habermas 1991, 227).

- The limitation of freedom of association and assembly: big political and economic organisations "enjoy an oligopoly of the publicistically effective and politically relevant formation of assemblies and associations" (Habermas 1991, 228).

Habermasian public sphere analysis with the help of the epistemological method of immanent critique compares an actual public sphere (political economy and political communication) to the ideal and values of the public sphere that bourgeois society promises (freedom of speech, freedom of public opinion, freedom of association, freedom of assembly). The public sphere is a concept of immanent critique for criticising the shortcomings of societies. Habermas does not necessarily say that it exists everywhere, but that it should exist. Immanent critique compares proclaimed ideals to reality. If it finds out that reality permanently contradicts its own ideals, then it becomes clear that there is a fundamental mismatch and that reality needs to be changed in order to overcome this incongruity.

The bourgeois public sphere creates its own limits and thereby its own immanent critique. In capitalism, "the social preconditions for the equality of opportunity were obviously lacking, namely: that any person with skill and 'luck' could attain the status of property owner and thus the qualifications of a private person granted access to the public sphere, property and education. The public sphere [...] contradicted its own principle of universal accessibility" (Habermas 1991, 124). "Similarly, the equation of 'property owners' with 'human beings' was untenable; for their interest in maintaining the sphere of commodity exchange and of social labor as a private sphere was demoted by virtue of being opposed to the class of wage earners, to the status of a particular interest that could only prevail by the exercise of power over others" (Habermas 1991, 124f). "Under the conditions of a class society, bourgeois democracy thus from its very inception contradicted essential premises of its self-understanding" (Habermas 1991, 428). Thomas McCarthy interprets Habermas approach as arguing that the "Enlightenment's promise of a life informed by reason cannot be redeemed so long as the rationality that finds expression in society is deformed by capitalist modernization " (Habermas 1984, xxxvii).

That the public sphere is for Habermas (1991) a critical concept is also expressed by the related concept of the feudalisation of the public sphere. In the Theory of Communicative 
Action, Habermas $(1984,1987)$ reformulated the notion of the feudalisation of the public sphere as the colonisation of the lifeworld: "The thesis of internal colonization states that the subsystems of the economy and state become more and more complex as a consequence of capitalist growth, and penetrate ever deeper into the symbolic reproduction of the lifeworld" (Habermas 1987, 367). The "colonization of the lifeworld by system imperatives [...] drive[s] moral-practical elements out of private and political public spheres of life" (Habermas 1987, 325). The "imperatives of autonomous subsystems make their way into the lifeworld from the outside - like colonial masters coming into a tribal society - and force a process of assimilation upon it" (Habermas 1987, 355).

The colonisation of the lifeworld (Habermas 1984, 1987) results in the centralisation of economic power (companies, market concentration, monopolies) and political power (state, bureaucracy). Bureaucratisation is a transformation through which "the state was infused into [civil] society (bureaucracy) and, in the opposite direction, through which [civil] society was infused into the state (special-interest associations and political parties)". Monetarisation and commodification transmogrify the public sphere into "a sphere of culture consumption" that is only a "pseudo-public sphere" (Habermas 1991, 162) and a "manufactured public sphere" (Habermas 1991, 217).

But the two concepts of feudalisation and colonisation are not just negative forms of critique, but imply the possibility of a reversal - processes of decolonization, lifeworldisation, commonification so that communicative action substitutes the systemic logic of money and power and participatory democracy and spaces of co-operation emerge. Thomas McCarthy's in the preface to the Theory of Communicative Action defines decolonisation as the "expansion of the areas in which action is coordinated by way of communicatively achieved agreement". It sets "limits to the inner dynamic of media-steered subsystems and to subordinate them to decisions arrived at in unconstrained communication" (Habermas 1984, xxxvii).

Are ideology or hegemony better and more critical terms than the public sphere? They are certainly both critical terms needed in a toolbox of a critical theory of society, but only focus on the manipulation of information and consensus to domination and tend to remain idealistic, whereas the public sphere is an economic and political concept that focuses on the inclusiveness of ownership and decision-making. It allows stressing not only aspects of public discussion, but also the public or private ownership of crucial goods and services such as communications.

The postmodern critique points out that the public sphere has been a sphere of educated, rich men, juxtaposed to the private sphere that has been seen as the domain of women. Women, gays and lesbians, and ethnicities would have been excluded from the public sphere. It would therefore today be more promising that struggles against oppression take place in multiple subaltern counter publics than in one unified sphere. The criticism also stresses that an egalitarian society should be based on a plurality of public arenas in order to be democratic and multicultural (Benhabib 1992, Fraser 1992, Eley 1992, Mouffe 1999, Roberts and Crossley 2004). Habermas agrees that his early account in The Structural Transformation of the Public Sphere (Habermas 1991), originally published in German in 1962, has neglected proletarian, feminist, and other public spheres (Habermas 1992, 425-430).

The danger of pluralistic publics without unity is however that they will in social struggle focus on mere reformist identity politics without challenging the whole, which negatively affects the lives of all subordinated groups, and that in an egalitarian society common communication media are needed for guaranteeing cohesion and solidarity and a strong democracy. Postmodernists and post-Marxists are so much occupied with stressing difference that they do not realise that difference can become repressive if it turns into a plurality without unity. One needs unity in diversity in order to struggle for participatory democracy and for maintaining this condition once it is reached. It is preferable and more effective to have a few widely accessible and widely consumed broad critical media than many small-scale special interest media that support the fragmentation of struggles. Nicholas Garnham argues in this context for the need of a single public sphere and says that the postmodernists risk "cultural relativism" if they do not see that democracy is in need of "some common normative dimensions" and "more generalized media" (Garnham 1992, 369). 
The cultural imperialism critique stresses that the public sphere is a Western enlightenment concept that Western societies use for trying to impose their political, economic and social systems on other countries. Jim McGuigan's formulates in this context a criticism of Nicholas Garnham's interpretation of Habermas: "we have to entertain the possibility that the global public sphere is a Western fantasy and perhaps a last gasp of its otherwise shaky bid for or to sustain global hegemony" (McGuigan 1998, 96).

Concerning the question if there is a global public sphere, Colin Sparks (1998) stresses that broadcasting is mainly national. "Global" stations such as CNN and BBC World would reach limited audiences that are mainly located in the West. They would also predominantly have Western-made and Western-focused contents. He therefore suggests to abandon the term global public sphere and to better use the term "imperialist, private sphere" (Sparks $1998,122)$. The public sphere is not only about information and communication, but also about ownership. Therefore the existence of transnational forms of media and communication doesn't imply the existence of a global public sphere.

Public spaces and public spheres are not specific to the West. The public teahouse is an old cultural practice and space in many parts of the world, such as in China, Japan, Iran, Turkey, UK. Di Wang (2008) compares the early $20^{\text {th }}$ century Chinese teahouse to the British public houses. It is a common space, where people from all walks of life go for different purposes. The Chinese word for teahouse is 茶館: (cháguăn).

Chengdu (成都) is the capital of the Southwestern Chinese province Sichuan (四川). It has about 7.7 million inhabitants in its urban core. "Teahouses in Chengdu, however, were renowned for their multiclass orientation. One of the 'virtues' of Chengdu teahouses was their relatively equality" (Wang 2008, 421). Women were first excluded, but by 1930 fully accepted. These teahouses were not just cultural spaces, but also political meeting points, where political debates took place and political theatre pieces were performed, which attracted not only citizens, but also government spies. Wang (2008) discusses the role of the Chengdu teahouses during the 1911 Railroad Protection Movement. Public meeting places are spheres of civil engagement that can turn into political spaces of communication and protest.

The public sphere is both process and space: "In periods of mobilization, the structures that actually support the authority of a critically engaged public begin to vibrate. The balance of power between civil society and the political system then shifts" (Habermas 1996, 379). Juha Kovisto and Esa Valiverronen (1996) see the public sphere not as domain, but as process of counter-hegemonic struggles. A public sphere emerges where people struggle for a better society and their struggle is a process of constituting the public that creates spatial domains of resistance in the public. The public sphere is simultaneously process and space. Social organisation turns into a public sphere when people act politically in common for a joint goal that fosters participatory democracy instead of economic and state power and when they use grassroots organisations and/or the occupation or creation of public space as political strategy. Neo-Nazis do not form a public sphere because their organization structures and goals are authoritarian, opposed to participatory democracy.

The various Occupy movements are movements, where protest and spaces of occupation converge. They created public spheres of political communication that they controlled in selfmanaged manner: Tahrir Square in Cairo, Egypt; Syntagma Square in Athens, Greece; Puerta del Sol in Madrid, Spain; Plaça Catalunya in Barcelona, Spain; Zuccotti Park in New York City, St. Paul's Cathedral's and Finsbury Square in London. This creation of public spheres not just took place in the West, but in many parts of the world in times of global capitalist and social crisis. In 2011, there were revolutions in Tunisia and Egypt and Yemen as well as major protests in countries such as Albania, Algeria, Armenia, Australia, Azerbaijan, Bahrain, Belarus, Belgium, Bolivia, Burkina Faso, Canada, Chile, China, Colombia, Czech Republic, Cyprus, Denmark, Djibouti, Finland, France, Georgia, Germany, Greece, Hong Kong, Hungary, India, Iran, Iraq, Ireland, Israel, Italy, Jordan, Kuwait, Lebanon, Libya, Macedonia, Malawi, Malaysia, Maldives, Mauritania, Mexico, Mongolia, Morocco, Netherlands, New Zealand, Nigeria, Norway, Oman, Palestine, Portugal, Russia, Saudi Arabia, Slovenia, Somalia, South Africa, South Korea, Spain, Switzerland, Sri Lanka, Sudan, Syria, Turkey, the United King- 
dom, the United States, Vietnam, Western Sahara. Common aspects of these protests were that many of them used the tactic of making space public and political and that these protests took place in a common crisis of society. Resistance is as old as class societies, so public spheres have been formed as resisting publics throughout the history of class societies.

\section{The Media and the Public Sphere}

For Habermas $(1984,1987)$, a medium is an entity that enables social relations. He distinguishes between the steering media of money and power on the one hand and unmediated communicative action on the other hand. Niklas Luhmann (1995) in contrast to Habermas argues that all social systems are communication systems and organise their communication around specific media and binary codes such as money and paid/unpaid in the economy or power and in office/out of office in politics. Communication is a social relation, in which humans interact mutually with the help of symbols and thereby create meaning of each other and the world. It is a constitutive feature of society and all social systems. Communication requires and is not possible without media: storage media (information technologies) such as paper, tapes, film reels, computer hard disks, DVDs, web space; transport media (communication technologies) such as the telephone, television, radio, e-mail; and collaborative media (technologies of co-operation) such as wikis and online communities.

Whereas property (such as money and other commodities) and power can certainly be seen as media of social relations, a specific feature of the media and communication system is that it communicates content created or co-created by human beings that is stored, interpreted and re-interpreted in order to make meaning of the world. In modern society, the cultural system is not isolated, but culture is mediated by money in the culture industry and power in political communication. The cultural system has its own economy and politics.

Figure 1 has pointed out that civil society and the public sphere are interfaces that connect culture, the economy and politics through the socio-cultural, the socio-political and the socio-economic sphere. All information media circulate ideas in public to a broad range of people. They are systems for publishing, i.e. the making-public of information. Media address people with information as private individuals in their cultural role, as members of communities of interests in the socio-cultural sphere, as citizens or politicians in the political realm, as activists in the socio-political sphere, as owners, managers or employees in the economic system, and as members of economic interest groups in the socio-economic realm. Confronted with content provided by the media, humans create, re-create and differentiate meanings of the world in various social roles. Figure 2 shows the interactions of the media systems with other parts of modern society. Media create public information (news, entertainment, user-generated content etc) that confronts humans in various social roles, in which they make meaning of the world based on this information. In order to create cultural content, workers in the media system rely to specific extent on humans in various social roles as information sources. These information sources tend to be asymmetrically distributed with politicians, governments, parties, celebrities, experts, companies and managers playing a significantly more important role than everyday citizens. The media system also requires inputs from the economic system (financing in the form of loans, money paid for content or audiences, subsidies, donations) and the political system (laws, regulation). 


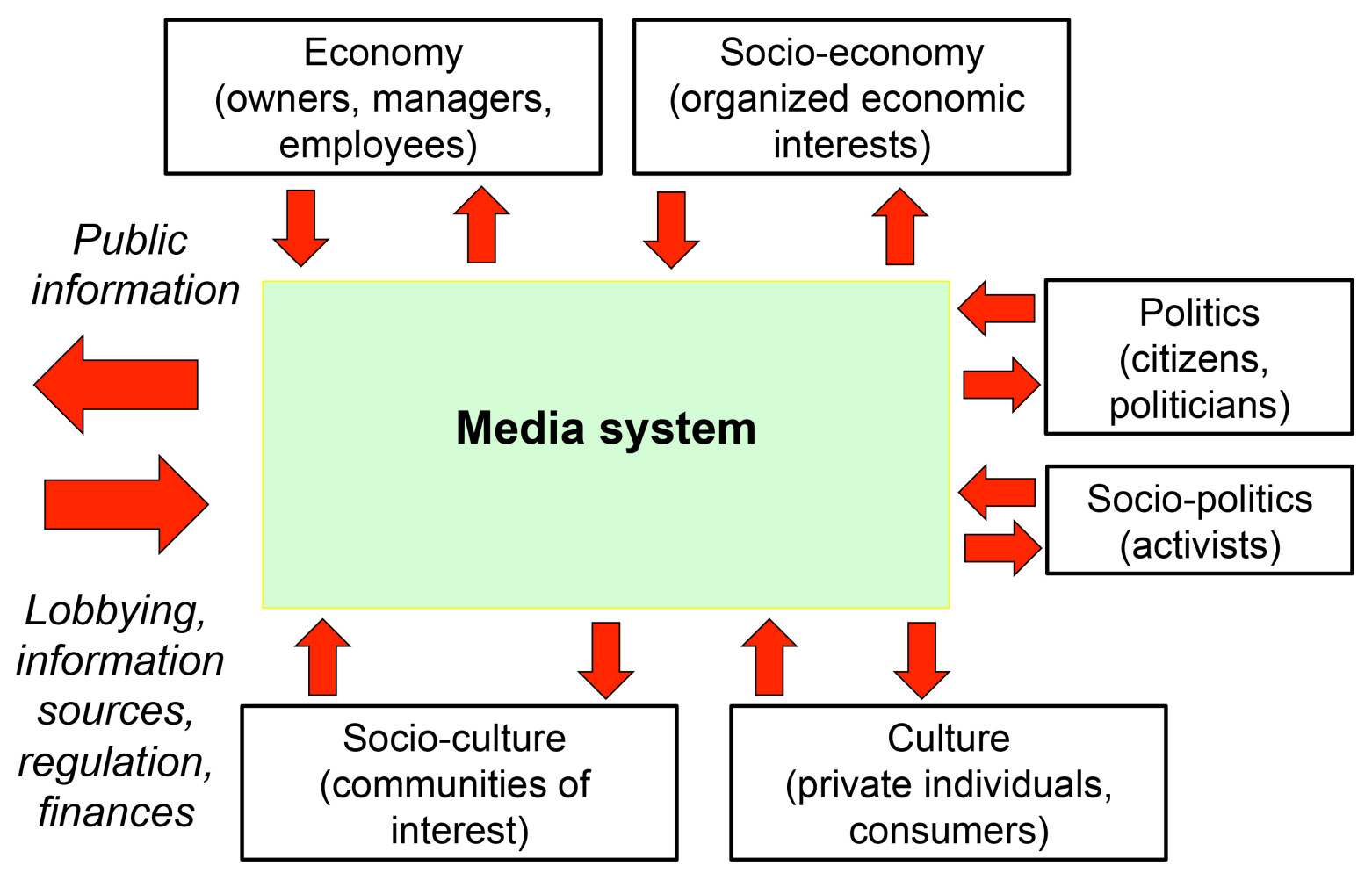

Figure 2: The media system in modern society

\begin{tabular}{|l|l|l|l|}
\hline $\begin{array}{l}\text { Organisation } \\
\text { form }\end{array}$ & CAPITAL & STATE & CIVIL SOCIETY \\
\hline Structures & Commodities & Public Goods & Gifts \\
\hline Structures & Prices & Taxes & Reciprocities \\
\hline Agency & Personal Possession & Shared Use & Co-Creation \\
\hline Agents & Consumers & Citizens & Communards \\
\hline Moral values & Liberty & Equality & Mutuality \\
\hline
\end{tabular}

Table 3: Three political economies of the media (Murdock 2011, 18)

Graham Murdock (2011) distinguishes between three political economies of the media in modern societies. Media can take on the form of commodities organised by capital, public goods organised by the state and gifts organised by civil society (see table 3 ).

Information media are specifically cultural in that they enable the creation, co-creation, diffusion and interpretation of symbols, by which humans make meaning of the world. Raymond Williams has argued against cultural idealism and for cultural materialism: He opposes "the separation of 'culture' from material social life" (Williams 1977, 19). We "have to emphasise cultural practice as from the beginning social and material" (Williams 1989, 206). The production of culture is an economic activity of production that creates ideas and meanings as usevalues. So culture is on the one hand always an economic process of production. On the other hand, culture is not the same as the economy, it is more than the sum of various acts of work, it has emergent qualities - it communicates meanings in society - that cannot be found in the economy alone. The economy is preserved in culture: culture is not independent from work, production and physicality, but requires and incorporates all of them. Based on 
Williams we can therefore say that information media have a) their specific culture that stores and communicates information in public and helps producing meaning and b) a specific mode of economic organisation of culture, a political economy of culture, that enables the ownership, control, production, diffusion and consumption of information. The media have an economic and a political dimension, they are owned in specific ways and are channels for political information and debate: "A newspaper or a TV channel is at one and the same time a commercial operation and a political institution" (Garnham 1990, 110). Table 4 distinguishes two levels of the organisation of information media and introduces based on Graham Murdock's typology a distinction between capitalist media, public media and civil society media.

\begin{tabular}{|l|l|l|l|}
\hline & Capitalist media & Public service media & $\begin{array}{l}\text { Civil society me- } \\
\text { dia }\end{array}$ \\
\hline $\begin{array}{l}\text { Economy } \\
\text { (ownership) }\end{array}$ & Corporations & State institutions & Citizen-control \\
\hline $\begin{array}{l}\text { Culture } \\
\text { (public cir- } \\
\text { culation of } \\
\text { ideas) }\end{array}$ & $\begin{array}{l}\text { Content that addresses } \\
\text { humans in various so- } \\
\text { cial roles and results in } \\
\text { meaning-making }\end{array}$ & $\begin{array}{l}\text { Content that addresses } \\
\text { humans in various social } \\
\text { roles and results in mean- } \\
\text { ing-making }\end{array}$ & $\begin{array}{l}\text { Content that ad- } \\
\text { dresses humans in } \\
\text { various social roles } \\
\text { and results in } \\
\text { meaning-making }\end{array}$ \\
\hline
\end{tabular}

Table 4: Two levels of the three political economies of the media

The media system has a public role for making information public. Public culture is however mediated by political economy and ownership structures (see table 4):

- Capitalist media are companies that are privately owned by single individuals, families or shareholders. They are culturally located in the public sphere, but at the same time they are part of the capitalist economy and therefore not only produce public information, but capital and monetary profit by selling audiences/users and/or content.

- Public media are funded by or with the help of the state and/or are created and maintained by a specific statute. They are seen as a public service that plays the role of providing political, educational and entertainment information to citizens. They are as organisations located in or close to the state system.

- Civil society media are full parts of the public sphere. They are economically related to the state if they receive subsidies and often stand in an antagonistic relation to the capitalist economy and governments because as alternative media they tend to reject for-profit and commercial logic and they tend to express alternative points of view that challenge governments and corporations. Civil society media are media that are run, owned and controlled by citizens as common projects. They express alternative points of view on the level of culture and have alternative organisation models at the level of political economy (Fuchs 2010, Sandoval and Fuchs 2010).

Media make information public on their cultural level, but only some of them are publicly controlled on the economic level by state-funded institutions or civil society, whereas capitalist media are profit-making corporations based on private ownership.

Habermas (1991) describes and criticises the commercialisation of the press since the middle of the $19^{\text {th }}$ century, that the idea of profit generation was introduced to the media, and advertising became common. The public sphere of the media would thereby have become undemocratic and a privatised realm controlled by powerful actors instead of citizens: "The communicative network of a public made up of rationally debating private citizens has collapsed, the public opinion once emergent from it has partly decomposed into the informal opinions of private citizens without a public and partly become concentrated into formal opinions of publicistically effective institutions. Caught in the vortex of publicity that is staged for show or manipulation the public of nonorganized private people is laid claim to not by public communication but by the communication of publicly manifested opinions" (Habermas 1991, 248). In a media world dominated by capitalism, the "world fashioned by the mass media is a 
public sphere in appearance only" (Habermas 1991, 171). Habermas critically observes that in capitalist media, publicity is not generated from below, but from above (Habermas 1991, 177).

James Curran (1991) argues that before 1850s there was a rich history of radical newspapers in the UK and that it was easy and cheap to create such newspapers. Examples of the radical $19^{\text {th }}$ century UK press are: Liberator, London Dispatch, Northern Star (a Chartist newspaper that existed from 1837 until 1852 and had a circulation of around 50 000), Political Register, Poor Man's Guardian, Reynolds News, Trades Newspaper, Twopenny Trash, Voice of the People, Voice of West Riding, Weekly Police Gazette (Curran and Seaton 2010, chapter 2). The radical press had an important role in radical politics and was associated with civil society groups such as the National Union of the Working Classes, the Chartist Movement, or the Society for Promoting the Employment of Women. Later advertising rose and it became ever more expensive to run a newspaper so that the press shifted towards the right and the labour press came to an end in the $20^{\text {th }}$ century. Curran argues that the $19^{\text {th }}$ century press had "a radical and innovatory analysis of society" and "challenged the legitimacy of the capitalist order" (Curran 1991, 40). Habermas would dismiss the role of the radical press, whereas $19^{\text {th }}$ century London press consisted of "conflicting public spheres" (Curran 1991, 42). Curran's position can be characterized as being close to Negt and Kluge's (1993) stress on a proletarian public sphere.

One should however see that Habermas' concerns about the economic colonisation of the life-world and the feudalisation of the media system show his concerns about capitalist media and his preference for non-capitalist media. Habermas' notion of the feudalised public sphere reflects Marx's (1842) concern that the "primary freedom of the press lies in not being a trade". Slavko Splichal (2007) stresses in this context that Ferdinand Tönnies and Karl Bücher shared Marx's insight that media can only constitute a public sphere if they are noncommercial. The public sphere has never materialized "because of unequal access to communication channels, uneven distribution of communicative competence, and the reduction of public debates to a legitimisation of dominant opinions created by either the 'business type' or the 'government type' of power elites" (Splichal 2007, 242).

There are several problems of how capitalist media limit the public sphere:

- Media concentration: There is a tendency that market competition results in concentration. In the commercial media landscape, the mechanism of the advertising-circulation spiral enforces media concentration (Furhoff 1973).

- Commercialised and tabloidised content: Advertising-financed media tend to more focus on entertainment than news, documentaries and educational programmes because this content is better suited for attracting advertisers (Jhally 1990, Smythe 1954, Williams 1990).

- Power inequalities: There are power differentials in commercial media that disadvantage individuals and groups that do not have significant shares of money, political influence and reputation and disempower their voices and visibility:

a) Private media ownership gives owners the possibility to influence media content.

b) For-profit and advertising logic makes media organisations dependent on market and commodity logic and prone to exclude voices that question these logics.

c) There is an educational and economic gap that can privilege educated and wealthy individuals in the consumption of demanding and costly culture.

There are general concerns about advertising culture (for an overview see the contributions in Turow and McAllister 2009):

- Advertising is product propaganda that conceals actual or possible negative features of products.

- Advertising only presents the products and ideologies of powerful companies and discriminates competing products and views and of less powerful actors, especially noncommercial and non-profit organizations.

- Advertising advances the concentration of the economy.

- Advertising advances media concentration (advertising-circulation spiral). 
- Advertisers try to manipulate humans' needs, desires, tastes, purchasing and consumption decisions.

- Advertising is mainly aimed at wealthy consumers.

- Advertising structures the corporate media as a filter in such a way that criticisms of corporate behaviour are avoided in order not to face loss of advertising clients.

- Advertisers try to calculate and make purely mathematical assumptions about human behaviour and interests (e.g. lives in a certain area, has a specific skin colour and age $=>$ has low income, no loan should be offered). They statistically sort consumers and users into groups and tend to discriminate especially the weak, people with low purchasing power and people of colour who as a consequence have disadvantages in society.

- Advertisements frequently contain and tend to enforce stereotypes, prejudices and biases. Examples are classist, racist and patriarchal stereotypes.

- Advertisements present women frequently in a sexist way.

- Advertising tends to violate consumer privacy and to use sensitive personal data for commercial purposes.

- Advertising fosters mass consumption of mostly non-renewable resources that end as waste in nature. Advertising aggravates the ecological crisis.

- Advertising fosters the programming of light entertainment and thereby advances the tabloidization of the media as well as the undermining of public service media/content.

Habermas' (1991, 175-195) main concern about advertising is that it has the potential to depoliticise the public. This would on the one hand be due to particularistic interests: "The public sphere assumes advertising functions. The more it can be deployed as a vehicle for political and economic propaganda, the more it becomes unpolitical as a whole and pseudoprivatized" (Habermas 1991, 175). On the other hand the influence of economic logic on the media would result in tabloidisation: "Reporting facts as human-interest stories, mixing information with entertainment, arranging material episodically, and breaking down complex relationships into smaller fragments - all of this comes together to form a syndrome that works to depoliticize public communication" (Habermas 1996, 377). Private control of the media can easily result in an "uneven distribution of effective voice" (Couldry 2010, 145). The economic and political-cultural dimensions of the public sphere are in this respect connected: "Having a voice requires resources" (Couldry 2010, 7). Voice requires a material form (Couldry 2010, 9). In order to be heard and seen, one needs resources that enable media power. Media are the main mechanisms of creating voice and visibility in society. Private ownership of the media can harm the public visibility of and attention to citizens' voices.

There has been a tradition of public service broadcasting in Europe and other parts of the world that has been a crucial dimension of the modern media system in the $20^{\text {th }}$ and $21^{\text {st }}$ centuries. Thinking of the BBC, most readers familiar with it will be able to come up with some points of criticism. It is however remarkable that since its inception in 1922 the BBC has by and large remained advertising-free in its UK-based core operations. Being advertising-free and funded either by a licence fee or taxes are features that the BBC shares with public broadcasting institutions in countries such as Finland, France, Spain, Sweden and Norway. Mixed public broadcasting systems that combine state-organized funding with advertising exist in contrast in countries such as Austria, Denmark, Germany, Hungary, Italy, the Netherlands, Poland, or Portugal. France and Spain have in recent years phased out advertisingbased funding on public broadcasting.

Public service media that are non-commercial and non-profit on the economic level embody values and relations "opposed to economic values and [...] essential to an operating democracy" (Garnham 1990, 111). Its cultural and political role is that it enables communication within the public sphere: "the collection and dissemination of information and the provision of a forum for debate" (Garnham 1990, 111). It has universal access obligations that enable "equal access to a wide range of high-quality entertainment, information and education" and ensure that "the aim of the programme producer is the satisfaction of a range of audience tastes rather than only those tastes that show the largest profit" (Garnham 1990, 120). Public service media's universal access principle means "the provision of a service of 
mixed programmes on national channels available to all" (Scannell 1989, 137).

By broadcasting and media in general, public information comes into private household and private affairs become public: "Broadcasting has created a public world of public persons who are routinely made available to whole populations. But at the same time it has brought private persons into the public domain" (Scannell 1989, 141). "Broadcasting, then, brings public life into private life, and private life into public life, for pleasure and enjoyment and enjoyment as much as for information and education" (Scannell 1989, 143). Besides these general characteristics, there are two important features of public media that distinguish them from privately controlled media:

- Common culture: They make culture commonly available to citizens: "European public service broadcasting has represented a real step forward in the attempt to create a common culture" (Garnham 1990, 126).

- Public ownership: Nicholas Garnham $(1990,132)$ stresses that public ownership and the non-profit and non-commercial status of the BBC is an important difference to the commercial media system that remains "the basis for its potential as a public service".

Habermas points out that the idea of the public sphere is connected to public services controlled and owned by the public: "In a democratic constitutional state, there are also public goods such as the undistorted political communication, that may not be tailored to the profit expectations of financial investors" (Habermas 2011, 101, translation from German ${ }^{3}$ ).

The BBC's structure reflects the commitment to the public sphere on a cultural and an economic level:

- Common culture:

The BBC's Royal Charter ${ }^{4}$ defines the BBC's public purposes:

"The Public Purposes of the BBC are as follows -

(a) sustaining citizenship and civil society;

(b) promoting education and learning;

(c) stimulating creativity and cultural excellence;

(d) representing the UK, its nations, regions and communities;

(e) bringing the UK to the world and the world to the UK;

(f) in promoting its other purposes, helping to deliver to the public the benefit of emerging

communications technologies and services and, in addition, taking a leading role in the

switchover to digital television" (BBC Royal Charter, §3).

The overall cultural task is "to inform, educate and entertain" (BBC Royal Charter, §5).

The BBC Agreement ${ }^{5}(\S 14,1)$ further specifies that the "content of the UK Public Services taken as a whole must be high quality, challenging, original, innovative and engaging".

- Public ownership:

The BBC's core activities are non-commercial: "The BBC as a corporation shall not directly provide any commercial services, but it may carry out other trading activities" (BBC Agreement $\S 68,1)$. The BBC is a public trust: "The Trust is the guardian of the licence fee revenue and the public interest in the BBC" (BBC Royal Charter, §22). Its core activities are advertising-free: "The BBC is not permitted to carry advertising or sponsorship on its public services. This keeps them independent of commercial interests and ensures they can be run purely to serve the general public interest. If the BBC sold airtime either wholly or partially, advertisers and other commercial pressures would dictate its programme and schedule priorities. There would also be far less revenue for other broadcasters. The BBC is financed instead by a TV licence fee paid by households. This guarantees that a wide

\footnotetext{
3 "Im demokratischen Verfassungsstaat gibt es auch öffentliche Güter wie die unverzerrte politische Kommunikation, die nicht auf die Renditeerwartungen von Finanzinvestoren zugeschnitten werden dürfen" (Habermas 2011, 101).

${ }^{4}$ http://downloads.bbc.co.uk/bbctrust/assets/files/pdf/about/how we govern/charter.pdf (accessed on December 11, 2013).

${ }^{5}$ http://downloads.bbc.co.uk/bbctrust/assets/files/pdf/about/how_we_govern/agreement.pdf (accessed on December 11, 2013)
} 
range of high-quality programmes can be made available, unrestricted, to everyone" (BBC Advertising Policy ${ }^{6}$ ).

The Communications Act $2003(\S 264,6)$ defines public service in a rather idealist manner as providing information, entertainment, education, cultural diversity, fair and well-informed news reporting, sports and leisure interests, science, religion, beliefs, social issues, international affairs, specialist interests, programmes for children and young people, and regional diversity. It neglects aspects of a public economy and therefore opens a door to the commercialisation of the BBC. "This made the idea of funding public content rather than, or even instead of, public service institutions thinkable" (Lunt, Livingstone and Brevini 2012, 118).

In recent years, scholars committed to the concept of public service have responded to the challenge of digital media and the increasing commercialisation of the media by introducing the notion of public service media (PSM). These activities have especially been organised around the bi-annual RIPE Conference Series (Re-Visionary Interpretations of the Public Enterprise) that has been organised since 2002. The "PSB role as the central force preserving the cohesion of society clearly needs to be safeguarded and, crucially, extended to the online world" (Jakubowicz 2007, 35).

Bardoel and Lowe (2007) point out cornerstones of the concept of public service media (PSM):

- The extension of public service from broadcasting to the media in general.

- In the age of digital media, public service audiences should not be targets of transmitted information, but partners and participants.

- Neoliberalism has put public funding of public service under commercial and market pressures that question its legitimacy ("waste of public money", "lack of audience interest"). Slavko Splichal (2007) gives a concise definition of PSM: "In normative terms, public service media must be a service of the public, by the public, and for the public. It is a service of the public because it is financed by it and should be owned by it. It ought to be a service by the public - not only financed and controlled, but also produced by it. It must be a service for the public - but also for the government and other powers acting in the public sphere. In sum, public service media ought to become 'a cornerstone of democracy'” (Splichal 2007, 255).

The European Commission (2009) uses the term public service media by stressing that these media enrich "public debate and ultimately can ensure that all citizens participate to a fair degree in public life" $(\S 10)$. "In this context, it must be recalled that the public service remit describes the services offered to the public in the general interest. The question of the definition of the public service remit must not be confused with the question of the financing mechanism chosen to provide these services" (§49).

The Committee of Minsters (2007) defines public service media the following way: "Public service media should offer news, information, educational, cultural, sports and entertainment programmes and content aimed at the various categories of the public and which, taken as a whole, constitute an added public value compared to those of other broadcasters and content providers".

Such policy definitions are in contrast to the one provided by Splichal idealist and culturalist. They ignore aspects of political economy that shape the way media are organised and can operate. They overlook the crucial implications of public ownership as well as of being non-profit and non-commercial. Idealist definitions of public service media advance the possibility to introduce the logic of commerce and commodification to public service and to ideologically and politically-economically mould them thereby into the logic of capitalism. Cultural idealism is an ideology that harms a true understanding of public service media. Public service media require a cultural-materialist definition and understanding of the public in public service.

Table 5 introduces a model of public service media that operates on three dimensions. There are economic, political and cultural dimensions of public service media: organisation, participation and content. On each level, there is the production, circulation and use of a

\footnotetext{
${ }^{6}$ http://www.bbc.co.uk/aboutthebbc/insidethebbc/howwework/policiesandguidelines/advertising.html (accessed on December 12, 2013).
} 
specific good that is organised in line with the logic of public service. So for example public ownership of PSM is an economic aspect of the means of communicative production.

\begin{tabular}{|c|c|c|c|c|}
\hline Sphere & Media & Production & Circulation & Use \\
\hline $\begin{array}{c}\text { Culture: } \\
\text { social meaning }\end{array}$ & Content & $\begin{array}{c}\text { Independence, unity } \\
\text { in diversity, educa- } \\
\text { tional content }\end{array}$ & $\begin{array}{c}\text { Cultural com- } \\
\text { munication } \\
\text { and debate }\end{array}$ & $\begin{array}{c}\text { Cultural dialogue } \\
\text { and understand- } \\
\text { ing }\end{array}$ \\
\hline $\begin{array}{c}\text { Pollitics: } \\
\text { sions }\end{array}$ & Participation & $\begin{array}{c}\text { Independence, unity } \\
\text { in diversity (repre- } \\
\text { sentation of minority } \\
\text { interests and com- } \\
\text { mon affinity and } \\
\text { reference points for } \\
\text { society), political } \\
\text { information }\end{array}$ & $\begin{array}{c}\text { Political com- } \\
\text { munication } \\
\text { and debate }\end{array}$ & $\begin{array}{c}\text { Political dialogue } \\
\text { and understand- } \\
\text { ing }\end{array}$ \\
\hline $\begin{array}{c}\text { Economy: } \\
\text { property }\end{array}$ & $\begin{array}{c}\text { Organisation } \\
\text { and tech- } \\
\text { nology }\end{array}$ & $\begin{array}{c}\text { Nonnership } \\
\text { non-market }\end{array}$ & $\begin{array}{c}\text { Universal access, } \\
\text { universal availa- } \\
\text { bility of technolo- } \\
\text { gy }\end{array}$ \\
\hline
\end{tabular}

Table 5: A model of public service media

On the economic level, PSM are means of production, circulation and consumption. PSM's means of production are publicly owned. The circulation of information is based on a not-forprofit logic. Consumption is made available in principle to everyone by giving citizens easy access to PSM's technology and information. On the political level, PSM make available inclusive and diverse political information that can support political debate and the achievement of political understanding. On the cultural level, PSM provide educational content that has the potential to support cultural debate and the achievement of understanding in society.

\section{The Internet, Social Media and the Public Sphere}

The differentiation of modern society into various spheres, such as the capitalist economy, the state, civil society, and the sphere of the family and intimacy, has resulted in a division between what is considered the private sphere and the public sphere. The modern idea of privacy stands in the context of the division of spheres.

\begin{tabular}{|l|l|}
\hline Private & Public \\
\hline individual & social \\
\hline family & society \\
\hline economy & polity \\
\hline civil society & state \\
\hline life world & systems world \\
\hline agent/action & structure \\
\hline everyday life & structure/system/power \\
\hline nature & culture \\
\hline feelings & reason \\
\hline freedom & power \\
\hline arts & sciences \\
\hline personal & political \\
\hline negative frdom & positive freedom \\
\hline
\end{tabular}

Table 6: Dualities associated with the private/public distinction (source: Garnham 2000, 174) 
Historically, the division of labour has brought about separations of spheres such as work time/free time, work place/household, paid/unpaid, urban/rural, wage/reproductive labour, mental/physical labour, men/women, developed/developing world, industry/agriculture. Such divisions of spheres are also divisions of power. Nicholas Garnham $(2000,174)$ argues that the division between private/public is a typically "Western post-Enlightenment" thought and practice that is associated with a number of other divisions that are shown in table 6 .

In modern society, we associate the realms of intimacy/family and the economy as the realm of private ownership with the private realm, whereas we associate the state, civil society and the media with the public realm. There are different definitions of privacy (Fuchs 2011) that share as the least common denominator that they all have to do with the question if and which spaces, behaviours, communications and data that concern individuals and groups should be available and accessible to others or not. According to Hannah Arendt, the distinction between the private and the public sphere is relevant for the privacy concept because it entails "the distinction between things that should be shown and things that should be hidden" (Arendt 1958, 72). Privacy has to do with the question what dimensions of human life should be made visible to the public or should remain invisible. Many of us may feel uncomfortable about the idea that advertisers and employers get access to the health databases of our general practitioners and hospitals because we may fear that patients may get harmed. Figure 3 shows a research result that indicates that Internet users are sceptical about the sharing of health data.

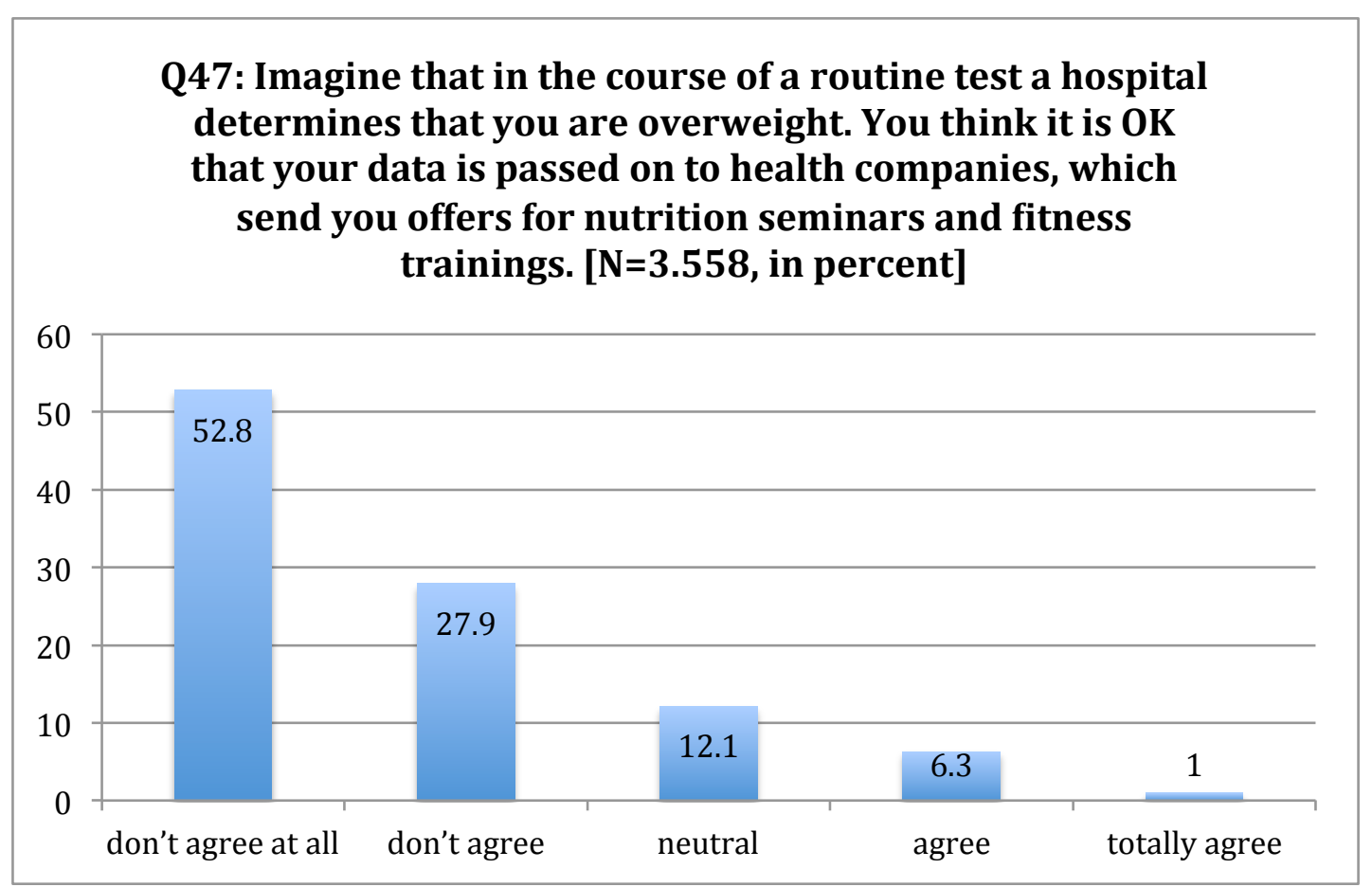

Figure 3: Result from research conducted in the research project "Social networking sites in the surveillance society" (see: http://www.sns3.uti.at, Kreilinger 2014)

We may not feel the same discomfort as in the case of health data sharing about the idea to abolish anonymous bank accounts in Switzerland that companies and wealthy people use for offshoring profits and income in order to evade paying taxes in their countries of residence. But both issues are discussed under the topic of privacy - health privacy and financial privacy.

The connection between privacy and private property becomes apparent in countries like Switzerland, Liechtenstein, Monaco, or Austria that have a tradition of relative anonymity of bank accounts and transactions. Money as private property is seen as an aspect of privacy, about which the public have no or only very restricted information. In Switzerland, bank secrecy is defined in the Federal Banking Act (§47). The Swiss Bankers Association sees bank 
anonymity as a form of "financial privacy" that needs to be protected and of "privacy in relation to financial income and assets"8. In most countries, information about income and the profits of companies (except for public companies) is treated as a secret, a form of financial privacy. The problem of secret bank accounts and transactions and the intransparency of richness and financial flows is not only that secrecy can in the economy supports tax evasion, black money, and money laundering, but also that financial privacy masks wealth gaps. Financial privacy reflects the classical liberal account of privacy. So for example John Stuart Mill formulated a right of the propertied class to economic privacy as "the owner's privacy against invasion" (Mill 1848, 43).

A further criticism of the privacy concept has been that it helps confining women to the household and shielding domestic violence. Seyla Benhabib (1992, 89f) says in this respect that the distinction between the private and public realm has "served to confine women and typically female spheres of activity like housework; reproduction; nurture and care for the young, the sick, and the elderly to the 'private' domain". Anita Allen summarises the feminist criticism of privacy in the following words: "Under fading regimes of patriarchy, privacy is the place where men lord over women and is the excuse that the state uses to justify letting them do it" (Allen 2003, 42). The right to bodily privacy can however also physically protect victims of violence from the offenders.

- The brief discussion shows that discussing privacy requires us to ask: For whom shall privacy be guaranteed or limited for which purpose and in which context (Fuchs 2011)? Privacy is a social, contextual and relational moral value (Fuchs 2011).

The emergence of "social media" is embedded into the trend that boundaries between the dualities of modernity have become somewhat liquid and blurred: we find situations where the distinctions between play and labour, leisure time and work time, consumption and production, private and public life, the home and the office have become more porous. Concepts such as digital labour, online prosumption, consumption work, produsage, crowdsourcing, freeconomy or playbour (play labour) have been used to describe transformations in the media, culture and society associated with social media. The liquefaction of boundaries is not, as Zygmunt Bauman (2005, 2000/2012) says in an overarching claim, the main feature of modernity today. It is more modest to assume that it is one of modernity's tendencies besides other features such as commodification, financialisation, informatisation, mediation, globalisation, or individualisation. I would therefore not speak of liquid life, liquid world and liquid modernity, as Bauman $(2005,2000 / 2012)$ does. Liquefaction may be the outcome of a number of developments in society:

- The globalisation of society, the economy and culture.

- Increased mobility and the transnational flows of workers, people, capital, information, finance, goods and services.

- Neoliberal policies that deregulate employment and relatively decrease wages, which makes people work longer hours.

- The rise of a flexible mode of production.

- The job crisis that makes people commute longer time and distances to and from their workplaces.

- The constant quest for reducing production and circulation costs in order to increase profits.

Two examples of liquefaction: Around 1 million people commute in and out of London every weekday by rail and bus ${ }^{9}$. Table 7 shows results of a study that analysed how British rail passengers spend their time on the train and compared results for 2004 and 2010. This comparison is meaningful because the Amazon Kindle was introduced in the UK in 2009, Facebook in 2005 and the iPad in 2010.

\footnotetext{
${ }^{7}$ http://www.swissbanking.org/en/mobile/medienmitteilung-20130318, accessed on December 12, 2013.

8 http://www.swissbanking.org/en/bankkundengeheimnis.htm, accessed on December 12, 2013.

9 http://londontransportdata.wordpress.com/2012/01/16/long-run-trend-in-commuting-into-central-london/ (accessed on December 12, 2013).
} 


\begin{tabular}{|l|l|l|}
\hline & $\begin{array}{l}\text { Commuter activities 2004 } \\
\text { (some of the time during } \\
\text { journey) }\end{array}$ & $\begin{array}{l}\text { Commuter activities 2010 } \\
\text { (some of the time during } \\
\text { journey) }\end{array}$ \\
\hline $\begin{array}{l}\text { Reading for leisure on out- } \\
\text { ward journey }\end{array}$ & $47 \%$ & $46 \%$ \\
\hline $\begin{array}{l}\text { Window gazing, people } \\
\text { watching on outward journey }\end{array}$ & $50 \%$ & $45 \%$ \\
\hline $\begin{array}{l}\text { Text messages and phone } \\
\text { calls for personal reasons on } \\
\text { outward journey }\end{array}$ & $18 \%$ & $32 \%$ \\
\hline $\begin{array}{l}\text { Working or studying on out- } \\
\text { ward journey }\end{array}$ & $27 \%$ & $31 \%$ \\
\hline $\begin{array}{l}\text { Working or studying on re- } \\
\text { turn journey }\end{array}$ & $29 \%$ & $31 \%$ \\
\hline $\begin{array}{l}\text { Listening to } \\
\text { music/radio/podcast on out- } \\
\text { ward journey }\end{array}$ & $12 \%$ & $28 \%$ \\
\hline E-mails (outward journey) & & $20 \%$ \\
\hline Eating, drinking (outward) & $8 \%$ & $12 \%$ \\
\hline $\begin{array}{l}\text { Non-personal text messages, } \\
\text { phone calls (outward) }\end{array}$ & $7 \%$ & $18 \%$ \\
\hline $\begin{array}{l}\text { Talking to other passengers } \\
\text { (outward) }\end{array}$ & $11 \%$ & $11 \%$ \\
\hline Being bored (outward) & $13 \%$ & $13 \%$ \\
\hline Internet browsing (outward) & $16 \%$ & $13 \%$ \\
\hline Sleeping (outward) & $17 \%$ \\
\hline
\end{tabular}

Table 7: Activities that UK commuters' spent doing some of the time while travelling by rail, 2004 and 2010, N=26,221 (2004), 19,715 (2010) (data source: Lyons, Jain, Susilo and Atkins 2013)

The statistics show that commuters' most common activities have in 2010 been reading for leisure, gazing out of the window/watching people, working, using the phone for personal or non-personal reasons, listening to music or the radio, reading and sending e-mails. This shows that the commuter train is simultaneously a public and a private space, where those on the way to their jobs engage in personal activities for leisure, work activities and media use for both work and private activities. The commuter train is a liquid space, where work time and leisure time blur. For commuters the Internet and mobile phones play an important role as means of communication for both personal and work-related activities while on the move. Commuting is a mobile activity that brings people from their homes to their workplaces and back. Media are tools that allow commuters to use the daily commuting time for both work and leisure from mobile places, they are liquid technologies for the organisation of time and space.

According to statistics, there were 1.56 million freelancers in the UK in 2012, around 6\% of the total workforce (Kitching and Smallbone 2012). The largest group of freelancers around 265,000 or $17 \%$ - works in art, literature and the media (ibid). They make up $64.4 \%$ of all people working in this sector in the UK. There were 93300 (6\%) IT and telecommunications freelance professionals in 2011 (ibid.). Freelancers generate around $8 \%$ of the private sector's turnover (ibid.). $38 \%$ of UK freelancers work from home and other places, $26 \%$ only at home, $33 \%$ only outside of the home (ibid.). So $64 \%$ of UK freelancers work at or from home. Their home is at the same time the household for free time and their work place for leisure time. It is a liquid space. Broadcast Now conducted a UK Freelancer Survey in the 
media and cultural industries in $2012(\mathrm{~N}=656)^{10} .21 \%$ of the respondents worked more than 60 hours a week, nearly $50 \%$ more than 50 hours, and $56 \% 10$ hours or more a day. $47 \%$ earned less than $£ 25,000$. This shows that freelancers tend to work long hours. The liquefaction of the home and the work place and working time and leisure time they experience tends to be dominated by more time being occupied by labour. At the same time liquefaction does not mean a high income for most freelancers. Connected to the freelance economy is a crowdsourcing economy, in which companies try to find cheap or unpaid labour on the Internet with the help of platforms such as Amazon Mechanical Turk, eLance, oDesk, or PeoplePerHour.

The liquefaction of boundaries is not automatically good or bad, but under the current neoliberal framework the logic of private profit and state power colonises the blurring of boundaries so that the becoming-public of the private and the becoming-private of the public is colonised by the systems of the economy (commodification) and the state (bureaucratisation).

There are 2 constitutive features of how social media such as Facebook are connected to the liquefaction of boundaries (Fuchs and Trottier 2013):

- Integrated sociality: Social media enable the convergence of the three modes of sociality (cognition, communication, cooperation) into an integrated form of sociality. This means for example on Facebook, an individual creates a multi-media content like a video on the cognitive level, publishes it so that others can comment (the communicative level), and allows others to manipulate and remix the content, so that new content with multiple authorship can emerge. One step does not necessarily result in the next, but the technology has the potential to enable the combination of all three activities in one space. Facebook, by default, encourages the transition from one stage of sociality to the next, within the same social space.

- Integrated social roles: Social media such as Facebook are based on the creation of personal profiles that describe the various roles of a human being's life. On social media like Facebook, we act in various roles (as friends, citizens, consumers, workers, colleagues, fans etc), but all of these roles become mapped onto single social media-profiles that are observed by different people that are associated with our different social roles. This means that social media like Facebook are social spaces, in which social roles tend to converge and become integrated in single profiles.

A Facebook profile holds a1) personal data, a2) communicative data, a3) social network data/community data in relation to b1) private roles (friend, lover, relative, father, mother, child, etc.) b2) civic roles (socio-cultural roles as fan community members, neighbourhood association members, etc), b3) public roles (socio-economic and socio-political roles as activists and advocates), b4) systemic roles (in politics: voter, citizen, client, politician, bureaucrat, etc.; in the economy: worker, manager, owner, purchaser/consumer, etc.).

Figure 4 visualizes social roles and information processes on social media.

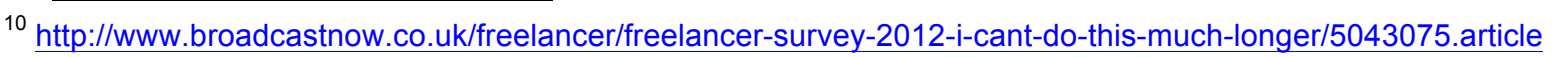
(accessed on December 12, 2013).
} 


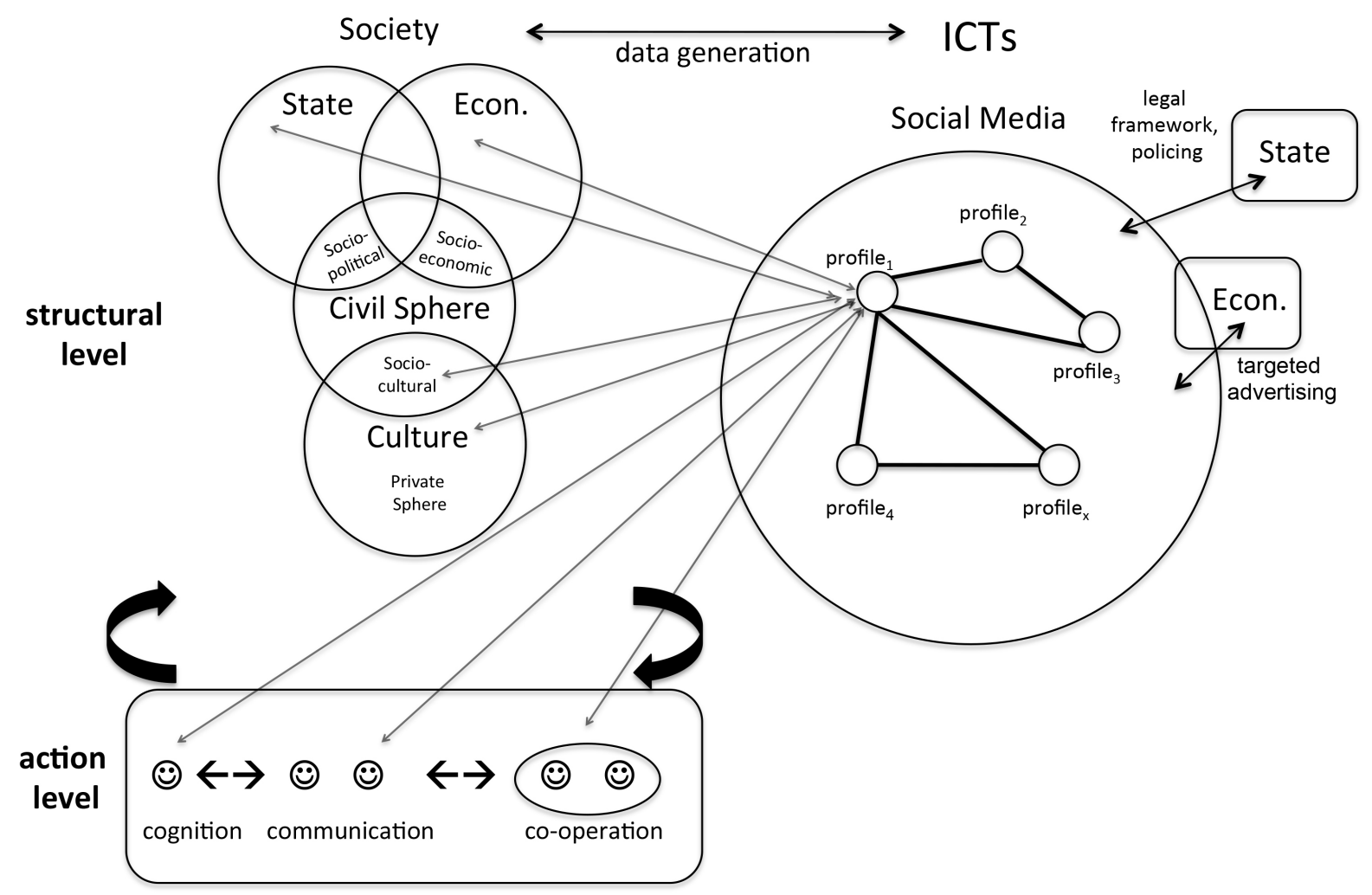

Figure 4: Social roles and information processes on social media (Fuchs and Trottier 2013)

Table 8 shows three basic antagonisms of contemporary social media. They are located in the realms of the economy, politics and civil society. I will for each dimension discuss how it relates to the public and the private realms.

\begin{tabular}{|l|l|l|}
\hline Sphere & \multicolumn{2}{|c|}{ Antagonism between... } \\
\hline Economy & $\begin{array}{l}\text { users' interest in data pro- } \\
\text { tection and corporate tax } \\
\text { accountability on the one } \\
\text { side ... }\end{array}$ & $\begin{array}{l}\text {.. and corporations' interest in user data's } \\
\text { transparency/commodification and corporate } \\
\text { secrecy on the other side }\end{array}$ \\
\hline Politics & $\begin{array}{l}\text { citizens' interest to hold the } \\
\text { powerful accountable and } \\
\text { protect communications } \\
\text { from powerful institutions' } \\
\text { access on the one side ... }\end{array}$ & $\begin{array}{l}\text { ferest to keep power structures secret and to } \\
\text { criminalise the leaking and making-public of } \\
\text { any data about them. }\end{array}$ \\
\hline Civil society & $\begin{array}{l}\text { networked protest commu- } \\
\text { nication that creates politi- } \\
\text { cal public spheres online } \\
\text { and offline ... }\end{array}$ & $\begin{array}{l}\text {... and the particularistic corporate and state } \\
\text { control of social media that limits, feudalises } \\
\text { and colonises these public spheres }\end{array}$ \\
\hline
\end{tabular}

Table 8: 3 antagonisms of social media

Social media's first contradiction concerns the economic level. Facebook's profits were US\$ 1.5 billion in 2013 (SEC Filings, form 10-K, January 31, 2014). Google's profits were US\$ 13.97 billion in the same time period (SEC Filings, form 10-K, annual report 2013). Twitter's net loss increased from US\$ 79.4 million in 2012 to US\$ 645.3 million in 2013 (SEC Filings, 
form EX-99.1, February 5, 2014). Given that Twitter is not making any profits, the question is if it was wise decision to list the company on the New York Stock Exchange in autumn 2013. On the day that Twitter's annual losses were announced, its stock market value on the New York Stock Exchanged dropped from US\$ 65 on February 5, 2014, to US\$ 50 on February 6 (data source: Yahoo! Finance). In contrast, Google's share price stood at the same time at almost US\$1200 and Facebook's share doubled its value from around US\$30 in 2012 to above US\$ 60 in February 2014 (data source: Yahoo! Finance). Where do corporate social media's profits come from?

On social media, users generate, upload and update personal, communicative and social network data stemming from their roles in the economy, politics, civil society and culture. In addition, many social media platforms retrieve and store data about user behaviour on their sites and the Internet in general. The data is partly kept private (visible only to single users), semi-public (visible to a group) or public (visible to everyone). Most corporate social media's capital accumulation model is to turn private, semi-public and public user data into a commodity that is sold to advertising clients that present targeted advertisements to users. Given that Facebook and Google's paid engineers alone only maintain platforms that without usage behaviour are devoid of sociality and economic value, it is reasonable to assume that corporate social media users are unpaid workers who generate economic value. In this context the notion of digital labour has been coined (see the contributions in Scholz 2013).

Dallas Smythe (1977) argued that on commercial broadcasting, audiences conduct labour that creates an audience commodity. On corporate social media, we can speak of an Internet prosumer data commodity generated by digital labour (Fuchs 2014a, chapters 4 and 11). It is qualitatively different from the audience commodity in a number of respects:

- Measuring audiences has in broadcasting and print traditionally been based on studies with small samples of audience members. Measuring user behaviour on corporate social media is constant, total and algorithmic.

- Audience commodification on social media is based on the constant real-time surveillance of users.

- User measurement uses predictive algorithms (if you like $A$, you may also like $B$ because 100000 people who like A also like B).

- User prices are often set based on algorithmic auctions (pay per view, pay per click)

Turning user data into a private good controlled by social media companies is legitimated with the help of privacy policies. Some examples:

- Google: "We use the information that we collect from all of our services to provide, maintain, protect and improve them, to develop new ones and to protect Google and our users. We also use this information to offer you tailored content - such as giving you more relevant search results and ads" (Google Privacy Policy, version from June 24, 2013)

- Facebook: "we may use all of the information we receive about you to serve ads that are more relevant to you" (Facebook Data Use Policy, version from November 15, 2013)

- Twitter: "When you use Twitter to follow, tweet, search or interact with Tweets, we may use these actions to tailor Twitter Ads for you. For example, when you search for a specific term, we can show you promoted content related to that topic. We also might tailor ads using your profile information or location, which may be based on your mobile device location (if you've turned on location features) or your IP address. This helps us show you local ads and other ads that you might prefer. Twitter may also tailor ads based on information that our ad partners provide us, like browser-related information (a browser cookie ID) or a scrambled, unreadable email address (a hash)" (How Twitter Ads Work, version from December 12, 2013). "If you prefer, you can turn off tailored ads in your privacy settings so that your account is not matched to information shared by ad partners for tailoring ads" (Twitter Privacy Policy, version from October 21, 2013).

- VKontakte: "The Site Administration has the right to dispose of the statistical information relating to the Site operation as well as of the Users' information to ensure the targeted display of advertising information to different audiences of Site users" (VKontakte Terms of Service, version from December 12, 2013)". 
- Weibo: "Sina Weibo may use your non-private personal information for marketing purposes, including but not limited to present or provide you with the advertising and promotional materials on Sina Weibo platform, notify you of or recommend Sina Weibo service or product information, and/or any other information that might be of interest to you based on your use of Sina Weibo service or product" (Weibo Privacy Policy, version from December 12, 2013).

"User agrees that Sina reserves the right to insert or add various kinds of commercial advertising or other types of commercial information (including but not limited to put advertisement on any webpage of Weimeng website), and, user agrees to accept product promotion or other relevant business information sent by Weimeng through email or other measures" (Weibo Terms of Use, version from December 12, 2013).

- Pinterest: "We also use the information we collect to offer you customized content, including: [...] Showing you ads you might be interested in" (Pinterest Privacy Policy, version from December 12, 2013).

- Instagram: "we may use information that we receive to: [...] provide personalized content and information to you and others, which could include online ads or other forms of marketing" (Instagram Privacy Policy, version from January 19, 2013)

Google, Facebook, Twitter, VKontake, Weibo, Pinterest and Instagram are some of the most used social media platforms in the world. They are all for-profit companies. One should not be mistaken by the fact that they offer communication services. They are not just communication companies, but also large advertising agencies. They all sell targeted ads and guarantee themselves the right to commodify users' private, semi-public and public data for this purpose in their privacy policies. Twitter limits this right somewhat by providing an optout option that allows users to have ads not "based on information shared by ad partners" (Twitter privacy settings, version from December 13, 2013). Targeted ads are however often based on data collected by the platform itself, not provided by ad partners, so that this limitation may only have very limited effects.

Users, privacy advocates and consumer protectionists tend to express concerns about corporate social media, especially about (see Fuchs 2014c):

- Very long or unlimited data storage;

- The lack of informed consent;

- Complex privacy policies and terms of use;

- Users' unpaid digital labour as business model;

- The privacy/free-access trade-off;

- The use of sensitive personal data for targeted advertising;

- The lack of consumer privacy in the light of personal data commodification;

- The lack of opt-in to and opt-out from targeted advertising;

- Liberal standard privacy settings;

- The difficulty of the full deletion of profiles;

- Networked data monitoring across platforms.

In a survey that was conducted as part of the research project "Social networking sites in the surveillance society" that I directed, around two thirds of the respondents felt that businesses handle personal data in inappropriate ways (figure 5 ). $82.1 \%$ said that web platforms should not use targeted advertising (figure 6). 


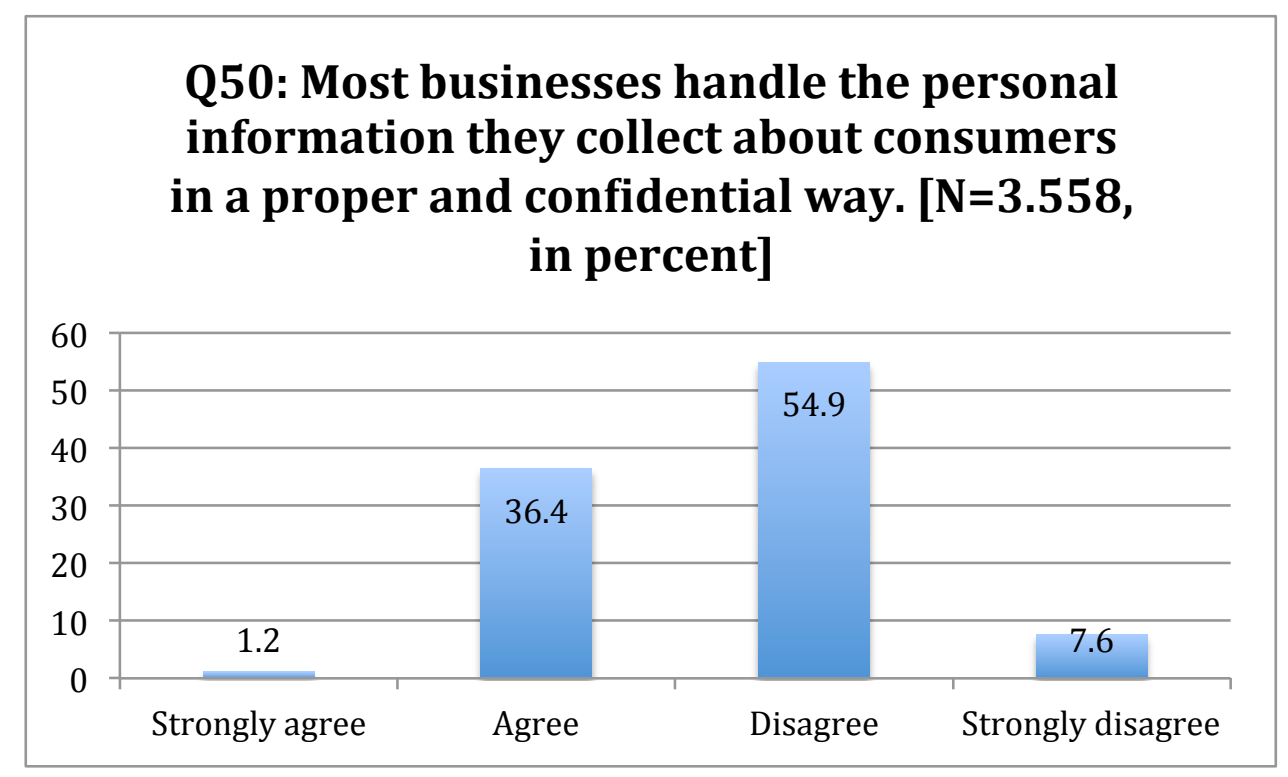

Figure 5: Research result from the project "Social networking sites in the surveillance society" (http://www.sns3.uti.at, Kreilinger 2014)

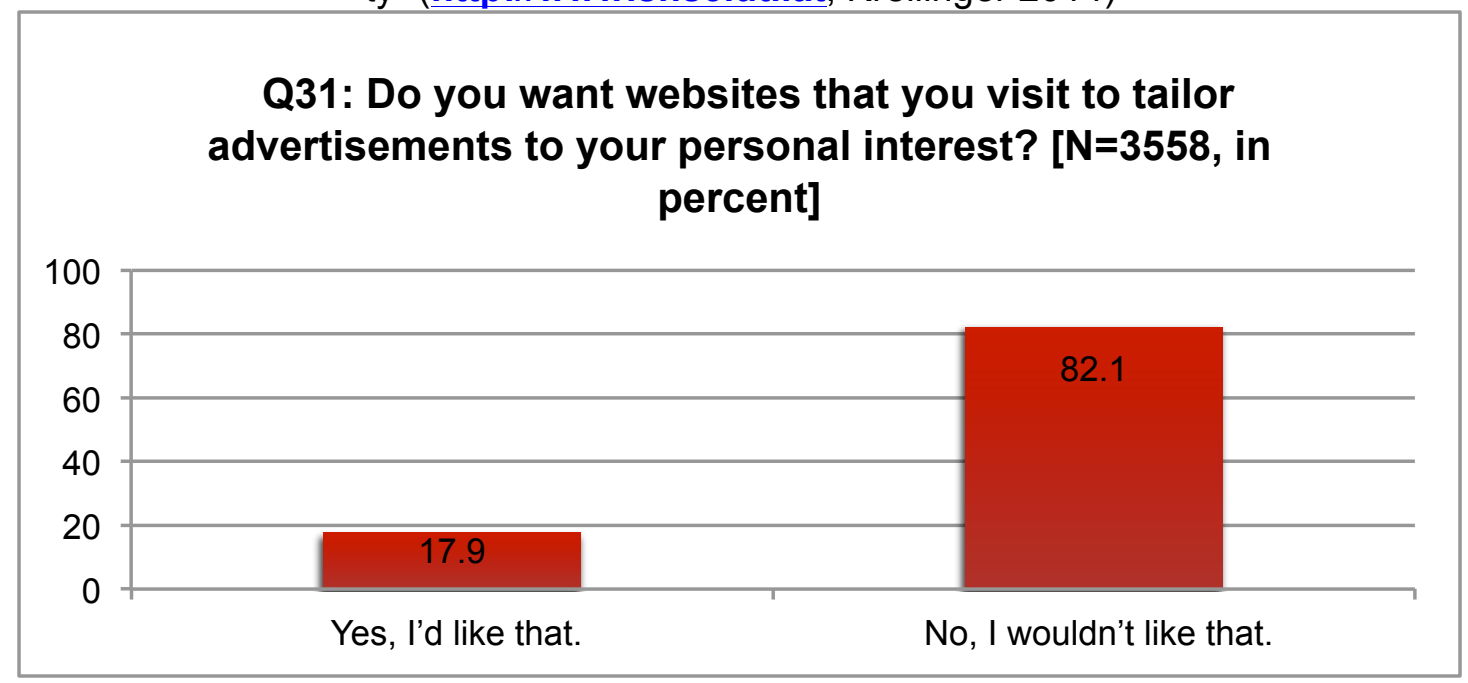

Figure 6: Research result from the project "Social networking sites in the surveillance society" (http://www.sns3.uti.at, Kreilinger 2014)

Such empirical data indicate that users feel that corporations in general violate consumer privacy and social media corporations in particular violate users' privacy by commodifying personal data. The economic value of the digital media industry is generated by a complex global division of labour that includes not just users' unpaid digital labour, but also the labour of slaves extracting conflict minerals in Africa, hardware assemblers working often under toxic and extremely hard conditions, highly paid and highly stressed software engineers in the West, precarious call-centre workers, freelance digital media professionals, or e-waste workers facing dangerous conditions (Fuchs 2014a).

Social media corporations' managers often express the view that privacy is outdated. Google's Executive Chairman Eric Schmidt said for example: "If you have something that you do not want anyone to know, maybe you should not be doing it in the first place"11 (http://www.youtube.com/watch?v=A6e7wfDHzew, accessed on February 15, 2011). Facebook's co-founder and CEO Mark Zuckerberg: "The goal of the company is to help people to

\footnotetext{
${ }^{11}$ http://www.youtube.com/watch?v=A6e7wfDHzew, accessed on December 13, 2013.
} 
share more in order to make the world more open and to help promote understanding between people"12. Schmidt and Zuckerberg argue for massive data sharing on social media. They however do not mention that this sharing is not primarily a sharing of data with friends and the public, but a sharing with Google and Facebook that are the largest data processors and data commodifiers in the world, which explains not just the recent rise of the term "big data", but also their interest in hiding their commercial interests ideologically behind the ideas of sharing and openness. Their claims are double-edged if one considers for example that Mark Zuckerberg in 2013 bought four estates that surround his house in Palo Alto's Crescent Park neighbourhood for US\$30 million. He is concerned about his privacy. Zuckerberg's logic is as simplistic as it is mistaken: "Privacy is good only if you can pay for it, it is not good if it makes Facebook or Google obtain less profits".

Social media corporations argue on the one hand against users' privacy, but on the other hand they are secretive about their own financial operations and by a complex global company structure try to establish financial privacy that makes their revenues and capital flows intransparent. Google has its European headquarters in Ireland, from where it organises its European revenues. From Ireland profits are transferred to the Netherlands and from there to the Bermuda Islands, where Google does not need to pay any corporation tax.

\begin{tabular}{|c|c|c|c|c|c|c|c|}
\hline Company & $\begin{array}{l}\text { UK } \\
\text { Reve- } \\
\text { nue } \\
2011(£)\end{array}$ & $\begin{array}{l}\text { Worldwide } \\
\text { Revenue } \\
2011 \text { (US\$) }\end{array}$ & $\begin{array}{l}\text { Worldwide } \\
\text { Profit be- } \\
\text { fore Taxes } \\
2011 \\
\text { (US\$) }\end{array}$ & $\begin{array}{l}\text { Gross } \\
\text { Profit } \\
\text { Rate } \\
2011 \\
\text { (in \% of } \\
\text { revenue) }\end{array}$ & $\begin{array}{l}\text { Estimated } \\
\text { Gross UK } \\
\text { Profit, } \\
2011 \text { (£) }\end{array}$ & $\begin{array}{l}\text { UK } \\
\text { Corpo- } \\
\text { ration } \\
\text { Tax } \\
2011 \text { (£) }\end{array}$ & $\begin{array}{l}\text { Estimated } \\
\text { Tax Reve- } \\
\text { nues at a } \\
\text { Corpora- } \\
\text { tion Tax of } \\
28 \%\end{array}$ \\
\hline Amazon & $3.3 \mathrm{bn}$ & $48.077 \mathrm{bn}$ & $934 \mathrm{mn}$ & $1.9 \%$ & $62.7 \mathrm{mn}$ & $1.8 \mathrm{mn}$ & $17.6 \mathrm{mn}$ \\
\hline Facebook & $175 \mathrm{mn}$ & $3.711 \mathrm{bn}$ & $1.695 \mathrm{bn}$ & $45.7 \%$ & $80.0 \mathrm{mn}$ & 238000 & $22.4 \mathrm{mn}$ \\
\hline Google & $395 \mathrm{mn}$ & $37.905 \mathrm{bn}$ & $12.326 \mathrm{bn}$ & $32.5 \%$ & $128.4 \mathrm{mn}$ & $6 \mathrm{mn}$ & $36.0 \mathrm{mn}$ \\
\hline
\end{tabular}

Table 9: Financial figures and estimates for Amazon, Facebook and Google. Data sources:

UK revenues: The Guardian Online, BBC Online; worldwide: Amazon SEC Filings 2012,

Form 10-K; Google SEC Filings 2012, Form 10-K; Facebook SEC Filings 2013, Form 10-K

Companies such as Google, Amazon and Starbucks had to appear before the UK Public Accounts Committee in late 2012 for discussing the question if they avoided paying taxes in the $\mathrm{UK}^{13}$. Amazon has 15000 employees in the UK, but its headquarters are in Luxembourg, where it has just 500 employees $^{14}$. In 2011 , it generated revenues of $£ 3.3$ billion in the UK, but only paid $£ 1.8$ million corporation tax $(0.05 \%)^{15}$. Facebook paid $£ 238000$ corporation tax on a UK revenue of $£ 175$ million $(0.1 \%)$ in $2011^{16}$.

Google has its headquarters in Dublin, but employs around 700 people in the UK ${ }^{17}$. Google's Managing Director for the UK and Ireland Matt Brittin admitted that this choice of location is due to the circumstance that the corporation tax is just $12.5 \%$ in Ireland ${ }^{18}$, where-

\footnotetext{
12 http://fuchs.uti.at/409/, accessed on December 13, 2013.

13 Starbucks, Google and Amazon grilled over tax avoidance. BBC Online. November 12, 2012. http://www.bbc.co.uk/news/business-20288077

${ }^{15}$ Amazon: £7bn sales, no UK corporation tax. The Guardian Online. April 4, 2012.

http://www.guardian.co.uk/technology/2012/apr/04/amazon-british-operation-corporation-tax. Google, Amazon, Starbucks: The rise of "tax sharing". BBC Online. December 4, 2012.

http://www.bbc.co.uk/news/magazine-20560359

${ }^{16}$ Should we boycott the tax-avoiding companies? The Guardian Online. Shortcuts Blog. October 17, 2012.

http://www.guardian.co.uk/business/shortcuts/2012/oct/17/boycotting-tax-avoiding-companies

${ }^{17}$ Google and auditor recalled by MPs to answer tax questions. The Guardian Online. May 1, 2013.

http://www.guardian.co.uk/technology/2013/may/01/google-parliament-tax-questions

${ }^{18}$ Starbucks, Google and Amazon grilled over tax avoidance. BBC Online. November 12, 2012.

http://www.bbc.co.uk/news/business-20288077
} 
as in the UK it was $26 \%$ in $2011^{19}$. Google had a UK turnover of $£ 395$ million in 2011 , but only paid taxes of $£ 6$ million $(1.5 \%)^{20}$. While large media companies only pay a very low share of taxes, governments argue that state budgets are small, implement austerity measures and as a result cut social and welfare benefits that hit the poorest in society.

In the House of Commons' Public Accounts Committee's inquiry on tax avoidance, Google's then UK Managing Director Matt Brittin admitted that this structure serves to pay low taxes. He said in the inquiry session conducted on May 16, 2013: "We talked about Bermuda in the last hearing, and I confirmed that we do use Bermuda. Obviously, Bermuda is a low-tax environment" ${ }^{21}$. Confronted with Google's low level of corporation tax paid in the UK, its Chairman Eric Schmidt said that "people we [Google] employ in Britain are certainly paying British taxes" ${ }^{\prime 2}$. His logic here is that Google does not have to pay taxes because its employees do.

Whereas social media corporations advocate openness, sharing of user data and an end of privacy in order to maximize profits, they claim closure, secrecy and financial privacy when it comes to their own global finance, profit and tax issues. Social media is facing an economic antagonism between users' interest in data protection and corporate tax accountability on the one side and corporations' interest in user data's transparency/commodification and corporate secrecy on the other side.

A comparable case from the world of the printed press that shows the contradictions of citizens and corporate interests is the UK phone hacking scandal, in which the News of the World newspaper has monitored the communications of public figures and published the obtained data as parts of its stories in order to achieve monetary profits from increased sales, attention and advertising revenues. The Leveson inquiry's report recommended a statutory regulation of the press that allows sanctions and fines in the case of privacy violations and libel. Stakeholders of the commercial press supported by the Tories opposed substantial legal measures with the argument that they would threaten the freedom of the press. The debate was shaped by an antagonism between the public's interest in protection from the media's invasion into their lives and the press' interest in making monetary profits protected by wide-ranging freedoms that allow journalistic investigations that deeply penetrate into all aspects of the human world.

The second contradiction of social media is on the political level. Edward Snowden's revelations about the existence of the Prism system have shed new light on the extension and intensity of state institutions' Internet and social media surveillance. According to the leaked documents, the NSA in the PRISM programme obtained direct access to user data from seven online/ICT companies: Aol, Apple, Facebook, Google, Microsoft, Paltalk, Skype, Yahoo! ${ }^{23}$. The Powerpoint slides that Edward Snowden leaked talk about collection "directly from the servers of these U.S. Service Providers" (ibid.).

The concept of the military-industrial complex stresses the existence of collaborations between private corporations and the state's institutions of internal and external defence in the security realm. C. Wright Mills argued in 1956 that there is a power elite that connects economic, political and military power: "There is no longer, on the one hand, an economy, and, on the other hand, a political order containing a military establishment unimportant to politics and to money-making. There is a political economy linked, in a thousand ways, with military institutions and decisions. [...] there is an ever-increasing interlocking of economic, military, and political structures" (Mills 1956, 7f).

Prism shows that the military-industrial complex contains a surveillance-industrial complex (Hayes 2012), into which social media are entangled: Facebook and Google both have

\footnotetext{
${ }^{19}$ In the UK, the main rate of corporation tax that applies for profits exceeding $£ 1,500,000$, was reduced from $28 \%$ in 2010 to $26 \%$ in $2011,24 \%$ in $2012,23 \%$ in 2013 and $21 \%$ in 2014.

20 http://www.bbc.co.uk/news/business-20288077

21 http://www.publications.parliament.uk/pa/cm201314/cmselect/cmpubacc/112/130516.htm (accessed on December 13, 2013).

22 http://www.bbc.co.uk/news/business-22245770 (accessed on December 13, 2013).

${ }^{23}$ NSA Prism program taps in to user data of Apple, Google and others. The Guardian Online. June 7, 2013. http://www.theguardian.com/world/2013/jun/06/us-tech-giants-nsa-data
} 
more than 1 billion users and are probably the largest holders of personal data in the world. They and other private social media companies are first and foremost advertising companies that appropriate and commodify data on users' interests, communications, locations, online behaviour and social networks. They make profit out of data that users' online activities generate. They constantly monitor usage behaviour for this economic purpose. Since 9/11 there has been a massive intensification and extension of surveillance that is based on the naïve technological-deterministic surveillance ideology that monitoring technologies, big data analysis and predictive algorithms can prevent terrorism. The reality of the murdering of a soldier that took place in the South-East London district of Woolwich in May 2013 shows that terrorists can use low-tech tools such as machetes for targeted killings. High-tech surveillance will never be able to stop terrorism because most terrorists are smart enough not to announce their intentions on the Internet. It is precisely this surveillance ideology that has created intelligence agencies' interest in the big data held by social media corporations. Evidence has shown that social media surveillance not just targets terrorists, but has also been directed at protestors and civil society activists ${ }^{24}$. State institutions and private corporations have long collaborated in intelligence, but the access to social media has taken the surveillanceindustrial complex to a new dimension: it is now possible to obtain detailed access to a multitude of citizens' activities in converging social roles conducted in converging social spaces.

Yet the profits made by social media corporations are not the only economic dimension of the contemporary surveillance-industrial complex: The NSA has subcontracted and outsourced surveillance tasks to around 2000 private security companies ${ }^{25}$ that make profits by spying on citizens. Booz Allen Hamilton, the private security company that Edward Snowden worked for until recently, is just one of these firms that follow the strategy of accumulation-bysurveillance.

According to financial data (SEC Filings, http://investors.boozallen.com/sec.cfm), it had 24 500 employees in 2012 and its profits increased from US\$ 25 million in 2010 to 84 million in 2011, 239 million in 2012 and 219 million in 2013. Surveillance is big business, both for online companies and those conducting the online spying for intelligence agencies.

Users create data on the Internet that is private, semi-public and public. In the social media surveillance-industrial complex, companies commodify and privatise these user data as private property and secret services such as the NSA driven by a techno-determinist ideology obtain access to the same data for trying to catch terrorists that may never use these technologies for planning attacks. For organising surveillance, the state makes use of private security companies that derive profits from organising the monitoring process. User data is in the surveillance-industrial complex first externalised and made public or semi-public on the Internet in order to enable users' communication processes, then privatised as private property by Internet platforms in order to accumulate capital, and finally particularised by secret services who bring massive amounts of data under their control that is made accessible and analysed worldwide with the help of profit-making security companies.

The social media surveillance-industrial complex shows that a negative dialectic of the enlightenment is at play in contemporary society: the military-industrial complex constantly undermines the very liberal values of the enlightenment, such as the freedoms of thought, speech, press and assembly as well as the security of the people's persons, houses, papers and effects. Prism shows how in supposedly liberal democracies dangerous forms of political-economic power negate enlightenment values.

Barack Obama commented on Prism that "you can't have a $100 \%$ security and also then have a $100 \%$ privacy and zero inconvenience" ${ }^{26}$. He expresses the view that maximising state security requires minimising citizens' privacy and extending surveillance. The privacysecurity-trade-off-model is flawed because it ignores that threats to state security tend to

\footnotetext{
${ }^{24}$ Spying on Occupy activists. The Progressive Online. June 2013. http://progressive.org/spying-on-ccupy-activists

${ }^{25}$ A hidden world, growing beyond control. Washington Post Online. http://projects.washingtonpost.com/top-secret-america/articles/a-hidden-world-growing-beyond-control/ ${ }^{26}$ Barack Obama defends US surveillance tactics. BBC Online. June 8, 2013. http://www.bbc.co.uk/news/world-us-canada-22820711
} 
derive from power inequalities and social insecurities in the world. The solution is not to undermine civil liberties by implementing, using and ever more surveillance technologies, but to foster equality and socio-economic security (human security) in the entire world.

The same institutions and politicians who want to minimise citizens' privacy and increase the state's access to personal data claim absolute secrecy for national security operations. Individuals and groups in civil society who oppose power asymmetries and inequalities in the world have made use of anonymous whistleblowing on the Internet in order to make data about the operations of powerful institutions transparent to the public. The powerful try to keep their key operations secret in order to better be able to maintain and extend their power. Data about it is put under particularistic control, it is kept secret. Whistle-blowers aim to make secret data about the powerful available to the public. WikiLeaks, Julian Assange, Bradley Manning and Edward Snowden are the most important examples. WikiLeaks understands itself as a watchdog of the powerful that exposes their power by leaking information (see also Fuchs 2014c, chapter 9): "WikiLeaks is a not-for-profit media organisation. Our goal is to bring important news and information to the public. [...] WikiLeaks interest is the revelation of the truth. Unlike the covert activities of state intelligence agencies, as a media publisher WikiLeaks relies upon the power of overt fact to enable and empower citizens to bring feared and corrupt governments and corporations to justice" 27 . Edward Snowden thinks that if the state threatens its citizens, the latter have to act and defend their rights: "I grew up with the understanding that the world I lived in was one where people enjoyed a sort of freedom to communicate with each other in privacy without it being monitored, without it being measured or analyzed or sort of judged by these shadowy figures or systems anytime they mentioned anything that travels across public lines. [...] I don't want to live in a world where everything that I say, everything I do, everyone I talk to, every expression of creativity or love or friendship is recorded. [...] So I think anyone who opposes that sort of world has an obligation to act in the way they can" ${ }^{\prime 2}$.

The US government and its allies oppose whistle-blowers in the name of national security and argue that military and secret service operations would have to remain secret. Barack Obama said about Snowden in this context that he is "putting at risk our national security and some very vital ways that we are able to get intelligence that we need to secure the country"29. Military judge Denise Lind explained Bradley Manning's sentence of 35 years in prison in a special report that Manning was "wrongfully and wantonly causing publication of intelligence belonging to the United States on the Internet knowing the intelligence is accessible to the enemy [...] The knowing conversions by PFC Manning deprived the United States government of the ability to protect its classified information"30. After Wikileaks' 2010 disclosure of information about the US' wars in Iraq and Afghanistan, Hillary Clinton commented: "The United States strongly condemns the illegal disclosure of classified information. It puts people's lives in danger, threatens our national security, and undermines our efforts to work with other countries to solve shared problems. [...] want you to know that we are taking aggressive steps to hold responsible those who stole this information. [...] People of good faith understand the need for sensitive diplomatic communications, both to protect the national interest and the global common interest" ${ }^{\prime 3}$.

The basic argument is that the US government has the right to keep data about its military and secret service operations, including the killing of civilians, secret. It argues that everyone making such secret information public threatens national security. The making-public of secret state data would be a crime. Powerful actors have a schizophrenic attitude: They argue that they should have the power to monitor citizens' private, semi-public and public data, but

\footnotetext{
${ }^{27} \mathrm{http}: / /$ www.wikileaks.org/About.html (accessed on December 13, 2013).

$28 \mathrm{http}$ ://mondoweiss.net/2013/07/i-dont-want-to-live-in-a-world-where-every-expression-of-creativity-or-love-orfriendship-is-recorded-full-transcript-of-snowdens-latest-interview.html (accessed on December 14, 2013).

${ }^{29} \mathrm{http}$ ///stream.wsj.com/story/campaign-2012-continuous-coverage/SS-2-9156/SS-2-298484/ (accessed on December 14, 2013).

${ }^{30}$ http://dissenter.firedoglake.com/2013/08/16/military-judge-announces-rationale-behind-verdict-in-bradleymannings-trial/ (accessed on December 14, 2013).

${ }^{31} \mathrm{http}: / /$ www.state.gov/secretary/rm/2010/11/152078.htm (accessed on December 13, 2013).
} 
that citizens shall not have access to data about the state's internal and external defence activities and that their making-public of such data is an offense that shall be penalised by several decades in prison.

On the political level of social media, there is an antagonism between civil society's interest to hold the powerful accountable and protect communications from powerful institutions' access on the one side and on the other side power holders' interest to keep power structures secret and to criminalise the leaking and making-public of any data about them.

The third antagonism of social media concerns the level of civil society. 2011 was a year of revolutions and rebellions in many parts of the world. In political protests that aim to establish a better society, activists form political public spheres that give a voice to citizens' demands. So 2011 should have been called the year of public spheres. However many called it the year of Twitter and Facebook revolutions, implying that it was social media that created the protest movements.

So for example Foreign Policy Magazine titled an article "The revolution will be tweeted"32 and the New York Times wrote that the "Egyptian revolution began on Twitter" ${ }^{\text {"33. There was }}$ talk about a "revolution 2.0" (Ghonim 2012) and in the scholarly world academics such as Manuel Castells $(2012,229)$ claimed that the "networked movements of our time are largely based on the Internet". I conducted an empirical study among activists who were involved in protests during the year 2011 in order to find out what role digital, social, mobile and other media had (Fuchs 2014b). 418 activists participated in an online survey. The survey contained one question that asked the respondents: "If you think back to a month, in which you were involved in Occupy protests, then how often did you engage in certain media activities for trying to mobilise people for a protest event, discussion, demonstration or the occupation of a square, building, house or other space?". The results are shown in table 10.

The data indicate that face-to-face communication, Facebook, e-mail, phone, SMS and Twitter are the most important media that Occupy activists employ for trying to mobilize others for protests. Activists use multiple media for mobilization-oriented communication. These include classical interpersonal communication via phones, e-mail, face-to-face and private social media profiles as well as more public forms of communication such as Facebook groups, Twitter and eMail lists. Posting announcements on alternative social media is much more uncommon than doing the same on Twitter and Facebook: Whereas $42 \%$ of the respondents posted protest announcements frequently on their Facebook profiles, only $4.4 \%$ did so on Occupii, $3.1 \%$ on $\mathrm{N}-1$ and $1.1 \%$ on Diaspora*.

\footnotetext{
${ }^{32}$ The Revolution will be tweeted. Foreign Policy Online. June 20, 2011.

http://www.foreignpolicy.com/articles/2011/06/20/the revolution will be tweeted\#sthash.fzgJPMdN.dpbs

${ }^{33}$ Spring awakening. How an Egyptian revolution began on Facebook. New York Times Online. February 17, 2012. http://www.nytimes.com/2012/02/19/books/review/how-an-egyptian-revolution-began-on-

facebook.html?pagewanted=all\&_r=0
} 


\begin{tabular}{|c|c|c|c|}
\hline & $\begin{array}{l}\text { Infrequently } \\
(0)\end{array}$ & $\begin{array}{l}\text { Medium } \\
(1-6)\end{array}$ & $\begin{array}{l}\text { Frequent- } \\
\text { ly }(>6)\end{array}$ \\
\hline $\begin{array}{l}\text { I had a personal face-to-face conversation in or- } \\
\text { der to mobilize others }\end{array}$ & $15.0 \%$ & $37.60 \%$ & $47.40 \%$ \\
\hline I sent an e-mail to personal contacts & $29.8 \%$ & $40.40 \%$ & $29.80 \%$ \\
\hline I phoned people & $36.9 \%$ & $39.50 \%$ & $23.60 \%$ \\
\hline I sent an SMS to my contacts & $49.7 \%$ & $27.00 \%$ & $23.30 \%$ \\
\hline I posted an announcement on an eMail list & $46.2 \%$ & $29.90 \%$ & $23.90 \%$ \\
\hline $\begin{array}{l}\text { I posted an announcement on my Facebook pro- } \\
\text { file }\end{array}$ & $25.2 \%$ & $32.40 \%$ & $42.00 \%$ \\
\hline $\begin{array}{l}\text { I posted an announcement on Facebook friends' } \\
\text { profiles }\end{array}$ & $53.1 \%$ & $21.10 \%$ & $25.80 \%$ \\
\hline $\begin{array}{l}\text { I posted an announcement in an Occupy group on } \\
\text { Facebook }\end{array}$ & $44.0 \%$ & $20.50 \%$ & $35.60 \%$ \\
\hline I posted an announcement on Twitter & $52.0 \%$ & $15.90 \%$ & $32.10 \%$ \\
\hline I created an announcement video on YouTube & $85.9 \%$ & $11.10 \%$ & $3.00 \%$ \\
\hline $\begin{array}{l}\text { I posted an announcement on my own profile on } \\
\text { the social networking site Occupii }\end{array}$ & $86.1 \%$ & $9.40 \%$ & $4.40 \%$ \\
\hline $\begin{array}{l}\text { I posted an announcement on friends' profiles on } \\
\text { the social networking site Occupii }\end{array}$ & $91.3 \%$ & $7.40 \%$ & $1.30 \%$ \\
\hline $\begin{array}{l}\text { I posted an announcement in an Occupy group on } \\
\text { the social networking site Occupii }\end{array}$ & $85.3 \%$ & $11.00 \%$ & $3.70 \%$ \\
\hline $\begin{array}{l}\text { I posted an announcement on my own profile on } \\
\text { the social networking site } \mathrm{N}-1\end{array}$ & $90.9 \%$ & $5.90 \%$ & $3.10 \%$ \\
\hline $\begin{array}{l}\text { I posted an announcement on friends' profiles on } \\
\text { the social networking site } \mathrm{N}-1\end{array}$ & $93.3 \%$ & $4.60 \%$ & $2.20 \%$ \\
\hline $\begin{array}{l}\text { I posted an announcement in an Occupy group on } \\
\text { the social networking site } \mathrm{N}-1\end{array}$ & $93.9 \%$ & $3.60 \%$ & $2.50 \%$ \\
\hline $\begin{array}{l}\text { I posted an announcement on my own profile on } \\
\text { the social networking site Diaspora* }\end{array}$ & $94.3 \%$ & $4.70 \%$ & $1.10 \%$ \\
\hline $\begin{array}{l}\text { I posted an announcement on friends' profiles on } \\
\text { the social networking site Diaspora* }\end{array}$ & $95.7 \%$ & $3.50 \%$ & $0.80 \%$ \\
\hline $\begin{array}{l}\text { I posted an announcement in an Occupy group on } \\
\text { the social networking site Diaspora* }\end{array}$ & $95.7 \%$ & $3.20 \%$ & $1.10 \%$ \\
\hline I wrote an announcement on a blog & $69.0 \%$ & $22.20 \%$ & $8.80 \%$ \\
\hline I informed people on meetup.com & $87.5 \%$ & $10.70 \%$ & $1.80 \%$ \\
\hline $\begin{array}{l}\text { I informed others by using one of the movement's } \\
\text { chats }\end{array}$ & $73.8 \%$ & $17.40 \%$ & $8.90 \%$ \\
\hline $\begin{array}{l}\text { I posted an announcement on one of the move- } \\
\text { ment's discussion forums }\end{array}$ & $67.6 \%$ & $22.00 \%$ & $10.30 \%$ \\
\hline $\begin{array}{l}\text { I made an announcement with the help of a } \\
\text { Riseup tool (chat, e-mail lists) }\end{array}$ & $84.7 \%$ & $11.00 \%$ & $4.30 \%$ \\
\hline $\begin{array}{l}\text { I made an announcement on an InterOccupy tele- } \\
\text { conference }\end{array}$ & $86.1 \%$ & $11.00 \%$ & $2.80 \%$ \\
\hline $\begin{array}{l}\text { I made an announcement with the help of the } \\
\text { OccupyTalk voice chat }\end{array}$ & $95.3 \%$ & $2.90 \%$ & $1.80 \%$ \\
\hline
\end{tabular}

Table 10: Frequency of usage per month of specific forms of communication in the mobilization of protest 
I also conducted a correlation analysis of the variables that cover protest mobilization communication. Some of the correlation results are presented in table 11.

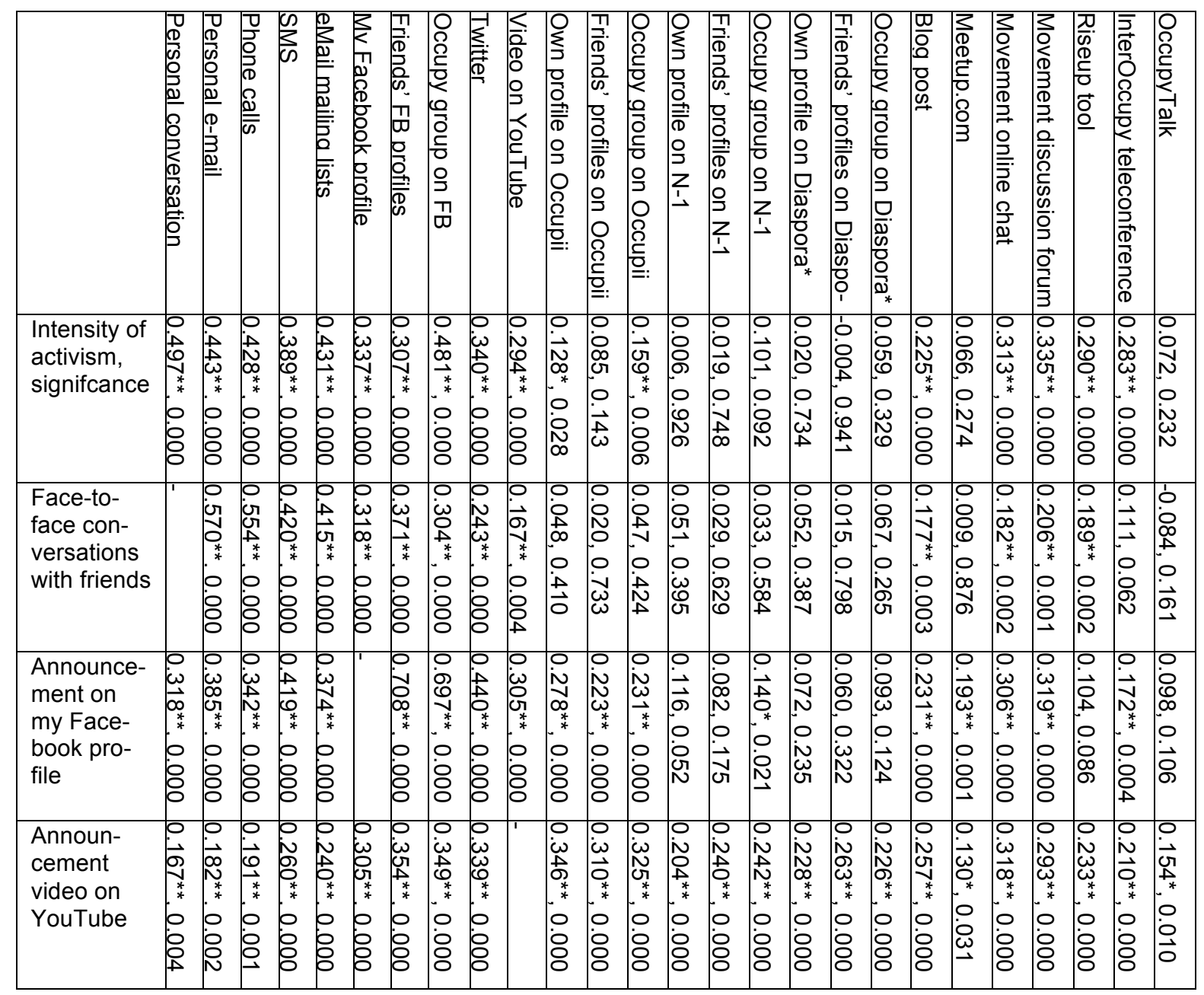

Table 11: Correlations between the frequency of specific forms of protest mobilization communication, activism intensity as well as political positioning (Spearman's rho)

Correlation analysis shows that a higher level of protest activity tends to result in a higher level of media use for protest mobilization. Mobilization in face-to-face communication tends to positively influence other forms of mobilization communication such as social media use's for spreading the word about protest events. The survey data is an empirical indication that contemporary protests are not social media rebellions and that at the same time digital and social media are also not irrelevant in these protests. Activists' make use of multiple media, both offline and online, technologically mediated and unmediated, digital and non-digital. The 2011 protests were activities that created occupied squares as public spheres and that organised themselves and voiced political demands offline and online and as combination of both.

$69.5 \%$ of the survey respondents said that the big advantage of commercial social media such as Facebook, YouTube and Twitter is that activists can reach out to the public and everyday people. Typically, respondents argued that "all the activists are already there [on social media], but so are regular people. I think it's one of the main goals of the Occupy movement to reach out to the rest of the 99\%" (\#63). At the same time $55.9 \%$ of the respondents indicated that state and corporate surveillance of activist communication is a huge disadvantage and risk that commercial social media pose. Activists expressed this fear for example in the following ways: "My Twitter account was subpoena'd, for tweeting a hashtag. The subpoena was dropped in court" (\#238). "Individuals I have supported have had Facebook accounts 
suspended, tweets catalogued as evidence against them, and this available information used for police to pre-emptively arrest them" (\#270). "The other risk is that commercial sites might collaborate with government or corporate interests to close down sites if a threat to their interests became apparent" (\#11). "Facebook = Tracebook. [...] We're contributing to capitalism by putting our content for free [on these sites]" (\#203).

Activists' use of corporate social media is facing a contradiction between possibilities for better communication and the risk of the corporate and state control of protest movements. Facebook, Google and other corporate social media are making billions of dollars in advertising revenue every year. They are part of the $1 \%$. So why should the $99 \%$ trust them and trust that these companies will deal with their data in a responsible manner? Edward Snowden's revelation of the Prism surveillance system shows the dangers of the surveillance-industrial complex, in which Google, Facebook and others collaborate with the National Security Agency (NSA).

Contemporary activists create public spaces of protest and make use of social media and face-to-face communication, online digital and offline non-digital media, in order to voice their political demands. At the same time they are confronted with the threat that both social media corporations and state institutions control corporate social media and thereby have the power to directly or algorithmically control political movements' internal and public communication capabilities. Civil society is facing an antagonism between networked protest communication that creates political public spheres online and offline and the particularistic corporate and state control of social media that limits, feudalises and colonises these public spheres.

\section{Towards Alternative Social Media as a Public Sphere}

The contemporary social media world is shaped by three antagonism: a) the economic antagonism between a) users' data and social media corporations' profit interests, b) the political antagonism between users' privacy and the surveillance-industrial complex as well as citizens' desire for accountability of the powerful and the secrecy of power, c) the civil society antagonism between the creation of public spheres and the corporate and state colonization of these spheres.

In Habermas' terms, we can say that social media has a potential to be a public sphere and lifeworld of communicative action, but that this sphere is limited by the steering media of political power and money so that corporations own and control and the state monitors users' data on social media. Contemporary social media as a whole do not form a public sphere, but are in a particularistic manner controlled by corporations and the state that colonise and thereby destroy the public sphere potentials of social media. The antagonistic reality of social media challenges classical liberalism's major assumptions.

John Locke $(1690,271)$, the founder of classical liberalism, argued that civil liberties and private property are natural laws and rights of human beings: "The State of Nature has a Law of Nature to govern it, which obliges every one: And Reason, which is that Law, teaches all Mankind, who will but consult it, that being all equal and independent, no one ought to harm another in his Life, Health, Liberty, or Possessions". David Hume (1739) made private property a central element of liberal theory, arguing that justice and private property require each other mutually in any society.

The autonomy of the will is for Kant $(1785,109)$ "the supreme principle of morality". "The principle of autonomy is thus: "not to choose in any other way than that the maxims of one's choice are also comprised as universal law in the same willing" (Kant 1785, 109). "Autonomy is thus the ground of the dignity of a human and of every rational nature" (Kant 1785, 101). Heteronomy would be the opposition of autonomy (Kant 1785, 95). Kantian autonomy means that people act freely if they accord to laws that they have given themselves (Habermas 2013, 70).

The consequence of Kant's principle of autonomy is the Golden Role as categorical imperative: "Act only according to that maxim by which you can at the same time will that it should become a universal law. [...] Act as though the maxim of your action were by your will 
to become a universal law of nature. [...] So act that you use humanity, in your own person as well as in the person of any other, always at the same time as an end, never merely as a means (Kant 1785, 71, 87). Habermas $(2008,140)$ argues that Kant's categorical imperative is reflected in the insight that freedoms are only limited by the freedom of others. Habermas $(2011,14)$ says that Kant's principle of autonomy and his categorical imperative is present in the Universal Declaration of Human Rights ${ }^{34} \$ 1$ : "All human beings are born free and equal in dignity and rights". As a further consequence of the principle of autonomy, Kant $(1784,4)$ saw the "public use of man's reason" for "addressing the entire reading public" as the main feature of the Enlightenment. It would enable "man's emergence from his self-incurred immaturity" (Kant 1784, 7). "The essence of such public reason is that it is always offered for possible critique by others" (Garnham 2000, 182).

John Stuart Mill $(1859,16)$ argued that there is a "portion of a person's life and conduct which affects only himself" and that this portion "is the appropriate region of human liberty". He derived from this assumption the liberties of conscience, thought, feeling, opinion, sentiment, expression, discussion, publication, tastes, pursuits and association. He also propagated an individualism that gives humans the right to pursue their own good in their own way: "No society in which these liberties are not, on the whole, respected, is free, whatever may be its form of government; and none is completely free in which they do not exist absolute and unqualified. The only freedom which deserves the name, is that of pursuing our own good in our own way, so long as we do not attempt to deprive others of theirs, or impede their efforts to obtain it" (Mill 1859, 17).

Mill $(1848,16 \mathrm{f})$ acknowledged that capitalism creates inequality and argued that freedom is preferable to equality: "The perfection both of social arrangements and of practical morality would be, to secure to all persons complete independence and freedom of action, subject to no restriction but that of not doing injury to others: and the education which taught or the social institutions which required them to exchange the control of their own actions for any amount of comfort or affluence, or to renounce liberty for the sake of equality, would deprive them of one of the most elevated characteristics of human nature".

Based on the liberal principles of liberty, individualism and private property, Adam Smith (1790) formulated the doctrine that the rich whom he considered to be naturally selfish "are led by an invisible hand to [...] advance the interest of the society" (215). He considered private property as fundamental human right and that one of the "most sacred laws of justice" (101) is to "guard his property and possessions" (102).

It becomes evident from this discussion that individual civil liberties are in liberal ideology connected to an individual right of private property that stands above considerations of socioeconomic equality, which is not considered as a fundamental right. Marx formulated in this context the critique that the individualism advanced by classical liberalism results in egoism that harms the public good. The rights to private property of the means of production and to accumulate as much capital as one pleases would harm the community and the social welfare of others who are by this process deprived of wealth: "The right of property is thus the right to enjoy and dispose one's possessions as one wills, without regard for other men and independently of society. It is the right of self-interest" (Marx 1843, 236). "Thus none of the so-called rights of men goes beyond the egoistic man, the man withdrawn into himself, his private interest and his private choice, and separated from the community as a member of civil society" (Marx 1843, 236f).

Crawford Macpherson (1962) has termed this critique of liberalism the critique of possessive individualism. Possessive individualism is the "conception of the individual as essentially the proprietor of his own person or capacities, owing nothing to society for them" (Macpherson 1962, 3). According to Macpherson, it is the underlying worldview of liberal theory since John Locke and John Stuart Mill. The problem of classical liberal is that relatively unhindered private accumulation of wealth, as the neoliberal regime of accumulation has shown since the 1970s, comes into conflict with social justice and is likely to result in strong socio-

\footnotetext{
${ }^{34}$ http://www.un.org/en/documents/udhr/ (accessed on December 13, 2013).
} 
economic inequality. The ultimate practical result of Mill's liberalism is an extreme unequal distribution of wealth.

Marx's also criticised that liberalism is highly individualistic. He said in this context that Kant stresses autonomy and human will as individual principles and thereby sees emancipation attainable by individual reason, not by social emancipation from class: "The key to the criticism of liberalism advanced by Saint Max and his predecessors is the history of the German bourgeoisie. [...] The state of affairs in Germany at the end of the last century is fully reflected in Kant's Critik der practischen Vernunft. While the French bourgeoisie, by means of the most colossal revolution that history has ever known, was achieving domination and conquering the Continent of Europe, while the already politically emancipated English bourgeoisie was revolutionizing industry and subjugating India politically, and all the rest of the world commercially, the impotent German burghers did not get any further than 'good will'. Kant was satisfied with 'good Will' alone, even if it remained entirely without result, and he transferred the realisation of this good will, the harmony between it and the needs and impulses of individuals, to the world beyond. Kant's good will fully corresponds to the impotence, depression and wretchedness of the German burghers, whose petty interests were never capable of developing into the common, national interests of a class and who were, therefore, constantly exploited by the bourgeois of all other nations" (Marx and Engels 1845, 208).

The Universal Declaration of Human Rights ${ }^{35}$ formulates the basic freedoms of thought (§18), opinion and expression (§19), assembly and association (§20). It also defines the freedom of property: "(1) Everyone has the right to own property alone as well as in association with others. (2) No one shall be arbitrarily deprived of his property" (\$17). Furthermore it defines social rights, such as that "Everyone, as a member of society, has the right to social security" (§22) and that "Everyone has the right to a standard of living adequate for the health and well-being of himself and of his family" $(\$ 25,1)$.

The criticism of possessive individualism points out that the freedom of private property questions social rights and that therefore $\S 17$ stands in a fundamental antagonism to $\S \S 22$ and 25. The Charter of Fundamental Rights of the European Union therefore limits the right to private property by the extension that "No one may be deprived of his or her possessions, except in the public interest and in the cases and under the conditions provided for by law, subject to fair compensation being paid in good time for their loss" $(\$ 17)^{36}$. The European Convention on Human Rights ${ }^{37}$ in a comparable way limits the freedom of private property by that a State may "enforce such laws as it deems necessary to control the use of property in accordance with the general interest or to secure the payment of taxes or other contributions or penalties" (article 1).

When Habermas argues that the stratification of ownership and education limits the freedom of speech and that the power of political and economic organisations limits the freedom of association and assembly (Habermas 1991, 227f) he just like the criticism of possessive individualism points towards specific limits of the liberal conception of the public sphere.

Horkheimer and Adorno (2002) argue that the liberal Enlightenment ideology turns into its own opposite that it initially questioned so that "irresistible progress is irresistible regression" (28). "Once harnessed to the dominant mode of production, enlightenment, which strives to undermine any order which has become repressive, nullifies itself" (Horkheimer and Adorno 2002, 73f). Although "freedom in society is inseparable from enlightenment thinking", the negative dialectic of freedom in capitalism is that the very concepts of enlightenment thinking, such as freedom, "no less than the concrete historical forms, the institutions of society with which it is intertwined, already contain[s] the germ of the regression which is taking place everywhere today" (Horkheimer and Adorno 2002, xvi). The freedoms proclaimed by liberal Enlightenment ideology find their actual violation in the practice of capitalism: The ideal of freedom turns into an opposite reality - unfreedom.

Alternative movements, groups and individuals such as Anonymous (Fuchs 2013), Wik-

${ }^{35}$ http://www.un.org/en/documents/udhr/ (accessed on December 14, 2013).

36 http://eur-lex.europa.eu/LexUriServ/LexUriServ.do?uri=OJ:C:2010:083:0389:0403:en:PDF

$37 \mathrm{http}: / /$ www.echr.coe.int/Documents/Convention_ENG.pdf 
iLeaks (Fuchs 2014c, chapter 9), Edward Snowden, Pirate Parties, privacy advocates, media reform movements such as Free Press in the USA and the Media Reform Coalition in the UK, the free software and open access movement, hacker groups, data protection organisations, consumer protection organisations, state and corporate watchdog organisations, and human rights activists point out the limits of the classical liberal conception of the public sphere: the actual practices of data commodification, corporate media control, as well as corporate and state surveillance limit the liberal freedoms of thought, opinion, expression, assembly and association. These movements and groups are the negative dialectic of the enlightenment of $21^{\text {st }}$ century informational capitalism. They show the difference of proclaimed essence and actual existence of liberalism. If Anonymous, for example, argues in favour of the freedom of assembly and expression of the Occupy movement and criticises police violence against activists, then it, on the one hand, stays within the categories of liberal thought. At the same time it shows how within the United States, the country in the world that most stresses the liberal value of freedom, freedom is actually limited by state action, which drives liberal values ad absurdum and shows their actual contradictory existence. The aforementioned actors conduct a practical immanent political critique of liberalism. They, however, frequently miss taking this form of critique to the next step and advancing from immanent critique towards a transcendental critique that sees the limits of the realisation of liberal values and calls for the establishment of a participatory democracy. The freedoms that reality today negates can only be realised in a society of equals, a participatory democracy.

Social movements such as Occupy go one step further and do not simply demand privacy rights for citizens or freedom of speech, but rather also stress that socio-economic inequality, the contradiction between the $99 \%$ and the $1 \%$, limits freedom (Fuchs 2014b). Occupy calls for the realisation of social rights together with individual rights in a realm of social and individual freedom that can best be described as participatory democracy.

But are there alternatives to the colonised Internet? Dal Yong Jin (2013) conducted an analysis of the most used Internet platforms and found that $98 \%$ of them were run by forprofit organisations, $88 \%$ used targeted advertising, $72 \%$ had their home base in the USA, $17 \%$ in China, $3 \%$ in Japan, $4 \%$ in Russia, $2 \%$ in the UK, $1 \%$ in Brazil, and $1 \%$ in France. He concluded that there is a "platform imperialism", in which "the current state of platform development implies a technological domination of U.S.-based companies that have greatly influenced the majority of people and countries" (Jin 2013, 154) and that "Chinese platforms [...] utilize the targeted advertising capital business model, which is not different from US Internet capitalism" (Jin 2013, 166). There were however 2 alternatives: BBC Online and Wikipedia. Reflecting Graham Murdock's (2011) distinction between three political economies, one can say that the Internet and social media are shaped by the logic of capitalism, public service and civil society. The power of these models is however asymmetrical and heavily skewed in favour of a capitalist Internet and capitalist social media.

Wikipedia is "is a multilingual, web-based, free-content encyclopedia project supported by the Wikimedia Foundation and based on an openly editable model"38. The Wikimedia Foundation is non-commercial and not-for-profit organization. The BBC Agreement describes BBC Online as "a comprehensive online content service, with content serving the whole range of the BBC's Public Purposes" 39 . On December 13, 2013, Wikipedia was the $6^{\text {th }}$ most accessed website in the world and the $9^{\text {th }}$ most visited in the UK ${ }^{40}$. BBC Online was the $56^{\text {th }}$ most popular website in the world and the $6^{\text {th }}$ most popular in the UK ${ }^{41}$. Wikipedia's civil society media model and BBC Online's public online service model differ from the for-profit models that have resulted in an Internet dominated by the logic of economic and political controls. They stand for the logic of a public service and commons-based Internet. What we need is not more market, advertising and commerce on social media, but more platforms that are based on the logics of the commons and public service. We need more visibility for them. And we

\footnotetext{
${ }^{38} \mathrm{http}: / /$ en.wikipedia.org/wiki/Wikipedia:About (accessed on December 13, 2013).

39 http://downloads.bbc.co.uk/bbctrust/assets/files/pdf/about/how we govern/agreement.pdf (accessed on December 11, 2013).

${ }^{40}$ Data source: alexa.com (accessed on December 13, 2013).

${ }^{41}$ lbid.
} 
need more resources for them. We need the decolonisation of the world and the Internet so that they are less based on bureaucratic and economic power and more on communicative rationality and the logic of the public sphere. It is no problem if more private information becomes public for communicative purposes if companies, the state and others do not have the power to misuse it and to harm citizens with it.

Graham Murdock $(2014,244)$ argues that resisting cultural commodification requires negatively "the resistance to commercial enclosure" and positively "a defence of communing". The latter should take on the form of projects that establish digital commons - "a linked space defined by its shared refusal of commercial enclosure and its commitment to free and universal access, reciprocity and collaborative activity" (Murdock 2005, 227). Public service institutions, such as broadcasters, museums, libraries and archives, are vast repositories of cultural commons. Making these commons available to the public in digital form and allowing the public to re-use and re-mix these commons for non-commercial purposes, can advance both digital commons and participatory culture. It is essential that culture can only be participatory if it is non-commercial and non-profit, otherwise participation can turn easily over into crowdsourcing value-generation and therefore the economic exploitation of the public, which destroys all participation and creates merely pseudo-participation.

One argument against public service social media is that it could give the state more power to control user data and thereby further enhance state surveillance. Public service does however not automatically imply state control, but only state funding. Public service institutions' are only truly public if they do not just have relative independence from the market, but also from government control of its contents. In order to minimise the state surveillance threat, user-generated content sites similar to YouTube that require large storage capacities, but do not contain lots of personal and communication data, could be increasingly organised by public service institutions such as the BBC and personal-data intensive social networking sites similar to Facebook by non-profit, non-commercial civil society organisations.

There is no guarantee that civil society-run social media are less prone to collaboration with secrete services than social media corporations such as Facebook and Google. They could by law be required to collaborate with secrete services. Social media run by activists and civil society are however more likely to lobby against such requirements than companies because they share and directly support activists' interests.

Another concern about public service online media is how to sustain high-quality public service content online if there is user-generated content. On the one hand journalists providing high-quality news and reports can work for alternative online platforms if funding becomes available for their work. On the other hand it should increasingly be realised that citizens' participation in debate and cultural production is a crucial democratic quality in itself. A public service participatory media structure is a high quality feature of democracy.

Especially since the 2009 revision of the EU Broadcasting Communication (Brevini 2013, 112-118), there is a tendency in Europe to limit public service media organisations' capacity to offer online services. The basic thought is that the licence fee's economic power can harm capitalist media markets. This line of argument overlooks however that big monopoly corporations such as Facebook and Google largely control the Internet and that the actually existing power asymmetry on the Internet comes from the profit logic of the market that centralises and dominates the Internet.

In Austria, the country I originally come from, a new public service broadcasting law that regulates the ORF (Österreichischer Rundfunk, Austrian Broadcasting) came into effect in 2010. It was the outcome of the EU DG Competition's decision that Austria had to revise its online services in light of the 2009 EU Broadcasting Communication and after the Austrian Newspaper Association (Verband Österreichischer Zeitungen) filed a complaint to the EU that that "ORF, using state funds, supplies online services such as games, dating services, computer and IT programs, GSM ring tones, sports platform and SMS services" and thereby 
causes a "pronounced distortion of competition to the detriment of newspaper publishers"42.

The new ORF law regulates in §4e that the ORF is only allowed to provide an overview of daily news and content accompanying broadcasts (sendungsbegleitende Inhalte) online. $\S 4 \mathrm{f}$ lists 28 online services that the ORF is not allowed to provide, including: forums, chats, usergenerated content sites, social networks, or online services for specialist groups. The new law meant the end of several of the ORF's online services, such as the Futurezone (a news site for Internet politics) and the FM4 and Ö3 Chats (chat forums for users).

The BBC Charter and Agreement do not contain such direct regulations that limit the provision of social media and online services. But there is a public value test for the introduction of new services. The UK was the first European country to introduce an ex ante-public value test that assesses with stakeholders if a new media service shall be introduced by a public service company or not in light of their cultural and market impacts. The EU Commission obliged Germany, Denmark, the Netherlands and Austria to introduce similar tests (Donders 2011).

The Public Value Test consists of a Public Value Assessment (PVA) that evaluates if a new service fulfils the BBC's public purposes and a Market Impact Assessment (MIA): "Account will be taken of both 'negative' substitution effects and 'positive' market creation effects. The MIA considers the extent to which the BBC's proposals are likely to induce substitution away from competing services and the ways in which that substitution may reduce investment in new services, and potentially reduce choice for consumers and citizens" (Ofcom 2007, 2).

"Were commercial providers to be deterred from seeking to offer competing services this would ultimately have the effect of reducing choice for listeners and viewers, to the detriment of the public interest as a whole" (Ofcom 2007, 3).

A crucial dimension is to assess if a potential BBC service limits the profitability of other media companies: "There is a very real concern that the BBC's services may distort competition" and because of the licence fee may make "commercial providers [...] unable to develop profitable offerings of their own" (Ofcom 2007, 11). "In the longer term, however, the negative impact on the revenues and profits of competing providers may lead to a reduction in investment and innovation. It could deter market entry by new providers or prompt existing suppliers to withdraw services. In other words, there may be longer term consequences which are detrimental to consumer interests" (Ofcom 2007, 13). Petros losifides (2010) shows that Ofcom's concern that public service media should be competitively provided is unique in Europe.

There are concerns that the BBC's licence fee can distort competition in the provision of online services. But the reality is that the logic of commerce distorts the capacity of the logic of public service and the commons to shape the Internet. Commerce has resulted in an antagonistic Internet dominated by targeted advertising and US communications companies that act as the world's largest advertising agencies, commodify data and support state surveillance of citizens. The current system has resulted in Prism. Market impact assessments put limits on the possibility to create public service alternatives to the commercial Internet. As result of the public value test, the $B B C$ had to abolish online services, such as its online education service BBC Jam, because they were considered as competition for commercial providers. BBC's Video Nation, audience-generated videos that were shown on the BBC from 1993-2011 and web-archived since 2011, had to close in 2011 because of cuts of the BBC Online's budget. The pilot of the BBC Creative Archive, the release of BBC archive material under a licence comparable to Creative Commons that enabled users to re-use it for noncommercial purposes, was discontinued in 2006, only a year after its introduction.

The UK and other European countries have a strong public service media tradition. Competing with Californian commercial social media companies is neither viable nor desirable. The best option is therefore that they focus on what they are. That they focus on creating public service and commons-based social media platforms. For this purpose existing laws

\footnotetext{
${ }^{42}$ European Commission: E/2 2008 (ex CP 163/2004 and CP 227/2005) - Financing of ORF. http://ec.europa.eu/competition/state_aid/cases/223847/223847_1014816_27_1.pdf
} 
would have to be adapted. Benedetta Brevini speaks in this context in her study of public service and the Internet in Europe of the need of Public Service Broadcasting 2.0 - "a new policy framework and a new set of public service imperatives that can bring those ideals into the online world" (Brevini 2013, 156) - so that "the online world is to be infused with the same public service ethos characterized traditional broadcasting and served Europe well for over 50 years" (Brevini 2013, 157). The question is of course if one shall in this context speak of public service broadcasting online/2.0 because this may imply to define the Internet by not just normative, but also communicative features of broadcasting, or if it is not an advantage to speak of a public service Internet or public service social media.

Karen Donders sees the public value test as "an instrument that inherently curbs public broadcasters' independence to some extent and attaches a particular importance to the market aspect of public intervention" and "a panic reaction to deal with aggressive private sector lobbying against a new media remit of public broadcasters" (Donders 2011, 29f). For Richard Collins, the UK's public value test is a Frankensteinian "regulatory tool designed to constrain and control public service broadcasters" (Collins 2011, 56; see also Barnett 2007). The call for public value tests is accompanied by the idea of top-slicing the licence fee so that parts of it are used for supporting public service content on commercial providers' media. 'Top-slicing will not be the end of the BBC, but it may be the beginning of the end" (losifides 2010, 28).

Neoliberal austerity measures have been the mainstream political answer to the financial crisis that had resulted from the financialization of the economy in combination with wage repression. First everyday people were deprived of wage increases and once the crisis hit their taxes were used to consolidated the banks and companies that are representatives of the system that deprived them in the first instance and then a second time.

These austerity measures in many countries mean cuts of public expenditure that hit the weakest and poorest. In Greece neoliberal responses to the capitalist crisis have resulted in the shutdown of the Hellenic Broadcasting Corporation (ERT) and the layoff of its more than 2500 employees. So neoliberalism deprives the people not just of material resources, but also of public communication resources.

Richard Collins $(2010,55 f)$ calls for "a radical shift in mentality - one that ceases to fetishise the traditional PSB and acknowledges the achievement and potential of the internet for delivery of public services and contents". Peter Goodwin argues that "for the BBC to survive in an increasingly web-based and digital world it needs to develop new web-based services" (Goodwin 2012, 70). A movement for public service media would need to be part of a larger project that challenges neoliberalism.

There are non-commercial and non-profit social media platforms such as Diaspora*, N-1, Occupii, InterOccupy, OccupyTalk, Occupy News Network, Occupy Streams, Riseup that withdraw social media from corporate control and make state control of activist communication more difficult. My survey showed that activists tend to see these alternative platforms as good alternatives to Facebook, Twitter and YouTube because they do not profit from users' activities and have better privacy protection mechanisms. But at the same time they stress that the problem is that these platforms have a low reach, operating them is resourceintensive and that there is the risk on these platforms to preach to the converted within an alternative ghetto that cannot reach a wider public (Fuchs 2014b). Activists said that such platforms are "owned and managed by us" and provide "more control of our content" (\#413). They "are secure, they are not full of ads and they have clearer parameters and more sophisticated tools" (\#113). "It is great to be focused and advertisement free. Also to have a network of like-minded individuals working together within a worldwide networked system. All great tools!" (\#123).

But survey respondents also argued that operating, using and maintaining alternative social media requires a large amount of different resources: "The maintenance of such platforms might take lots of time from the people working with it" (\#20). "Someone has to pay for them" (\#41). "Well, hosting these can get expensive, and you are not guaranteed donations, which might pose a problem" (\#329). "It requires time and man-power" (\#364).

Alternative media, online and offline, are facing a political-economic dilemma: they are on the one hand self-managed and tend to be more independent from the interests of the power 
elite whose domination activists want to challenge, but at the same time they are facing the power of media monopolies and oligopolies as well as the problem of mobilizing resources without state support and advertising. Alternative media are confronted with contradictions between critical voice and autonomy on the one side and resource precarity and lack of visibility on the other side (Fuchs 2014b, Sandoval and Fuchs 2010). As a consequence, the history of alternative media is also a history of voluntary self-exploitative labour. This circumstance is not activists' fault, but rather the consequence of the political economy of capitalism that limits the possibilities for civil society by making voice dependent on money and political resources. The oligopoly structure of social media has resulted in the circumstance that a few large transnational companies such as Facebook, Google and Twitter control the vast majority of social media use. Given oligopoly control, it is very difficult to establish alternatives that question the very principles that capitalist media are built on. Capitalist media structures limit the liberal freedoms of speech, opinion, expression, association and assembly. Liberalism is its own limit and immanent critique: liberal freedom of ownership limits citizens' liberal rights.

The survey respondents were very aware of the problems that alternative social media are facing (Fuchs 2014b). At the same time they saw the problems of how to organise alternative media in a capitalist world. The most popular suggestion is to collect voluntary donations. Voluntary donation models often face the problem of how to mobilise supporters and resources. There is the risk that only a small number of people donate continuously. Financial support can be highly uncertain and volatile, whereas organizing a successful alternative project in and against a capitalist media world requires continuity and stability.

My view is that improving the resource reality of alternative media in general and alternative social media in particular is a crucial democratic question of our time. The key is to overcome privately controlled media oligopolies, which requires media reforms. Large multinational companies, including Google, Facebook, Amazon and Apple, are avoiding paying taxes in a lot of the countries where they operate. This is not only unfair; it also increases the pressure for austerity measures in times of crisis.

If one takes the basic media reform funding idea of the UK Media Reform Coalition (http://www.mediareform.org.uk/), namely to tax large media corporations and to channel this income into non-commercial media, and combines it with elements of participatory budgeting, which allows every citizens to receive and donate a certain amount per year to a noncommercial media project, then elements of state action and civil society action could be combined: the power of the state would guarantee taxation of large companies, the distribution of this income to media projects would however be decentralized and put in the hands of citizens. Google, Facebook and other large online media companies hardly pay taxes in many countries. The insight that users are digital workers and create economic value on corporate social media that are financed by advertising allows changing global tax regulations: Corporate social media platforms should have to tax in a specific country that share of their revenues that corresponds to the share of users or ad-clicks/views in this country. Avoiding corporations' tax avoidance is a first step for strengthening the public sphere. The licence fee could be developed into a media fee paid by citizens and companies. It could be made more socially just than the licence fee by implementing it not as a flat but a progressive fee that varies based on salary and revenue levels. It is a matter of fairness that those who earn more contribute more to the organisation of the common interest and public good.

The media fee could partly be used for directly funding public service media's online presence and partly be used in the form of participatory budgeting to provide an annual voucher to every citizen that $\mathrm{s} /$ he must donate to a non-profit, non-commercial media organisation. So participatory budgeting should not be used for deciding if the BBC receives the full costs it needs for its operations. Additional income from the media fee could however be distributed to alternative media projects with the help of participatory budgeting. Non-profit versions of Twitter, YouTube and Facebook run either by institutions such as the BBC or by civil society could based on such a model serve the purpose of the public sphere and strengthen the democratic character of communications.

The Internet could become what Nancy Fraser terms a strong public sphere so that plat- 
forms are self-managed and "sites of direct or quasi-direct democracy, wherein all those engaged in a collective undertaking would participate in deliberations to determine its design and operation" (Fraser 1992, 135). Peter Dahlgren (1995) argues that a true public sphere requires a domain, in which "marginalized and oppressed groups would be assisted with financial and technical means to enable their participation on the advocacy domain" (Dahlgren 1995, 156). The system of a media fee combined with participatory budgeting could serve this purpose. It could enable alternative media to employ journalists, cultural workers and technicians in order to operate a common media system in a viable manner.

Habermas $(2008,136 f)$ suggests to extend public service to the quality press and provide state subsidies to it: "Concerning gas, electricity and water, the state is obliged to guarantee the population's supply with energy. Should it not also have such an obligation in the case of the type of 'energy' without whose influx dysfunctions emerge that damage the democratic state itself. It is not a 'system error' when the state tries to protect the public good of the quality press in particular cases" ${ }^{\prime 33}$ (Habermas 2008, 136f, translation from German). The concept of the participatory budgeted media fee (the participatory media fee) extends Habermas' idea from the realm of the press to the realm of digital media and introduces an element of participatory democracy to parts of the allocation process.

Media reforms, participatory budgeting and a reform of corporation tax could empower public service and alternative media's voice and visibility in the age of social media. It is time to occupy social media in order to withdraw them from corporate and state control and turn them into truly social media and a public sphere. Media reforms are needed for establishing a social media sphere that transcends particularistic control and represents the public interest so that the social potential of the media can be realised. Public service social media could overcome the Internet's antagonisms and serve the people.

\section{Social media is possible. A public service Internet is possible.}

\section{References}

Adorno, Theodor W. 2003 [1951]. Cultural Criticism and Society. In Can One Live After Auschwitz? A Philosophical Reader, ed. Rolf Tiedemann, 146-162. Stanford, CA: Stanford University Press.

Allen, Anita. 2003. Why Privacy Isn't Everything. Feminist Reflections On Personal Accountability. Lanham, MD: Rowman \& Littlefield.

Archer, Margaret S. 1995. Realist Social Theory: The Morphogenetic Approach. Cambridge: Cambridge University Press.

Arendt, Hannah. 1958. The Human Condition. Chicago: University of Chicago Press. $2^{\text {nd }}$ edition.

Bardoel, Jo and Gregory Ferrell Lowe. From Public Service Broadcasting to Public Service Media. In From Public Service Broadcasting To Public Service Media. RIPE@2007, ed. Gregory Ferrell Lowe and Jo Bardoel, 9-26. Gothenburg: Nordicom.

Barnett, Steven. 2007. Can the Public Service Broadcaster Survive? Renewal and Compromise in the New BBC Charter. In From Public Service Broadcasting to Public Service Media. RIPE@2007, ed. Gregory Ferrell Lowe and Jo Bardoel, 87-104. Gothenburg: Nordicom.

Bauman, Zygmunt. 2000/2012. Liquid Modernity. Cambridge: Polity Press.

Bauman, Zygmunt. 2005. Liquid Life. Cambridge: Polity.

Benhabib, Seyla. 1992. Models of Public Space: Hannah Arendt, the Liberal Tradition, and Jürgen Habermas. In Habermas and the Public Sphere, ed. Craig Calhoun, 73-98. Cambridge, MA: MIT Press.

Benkler, Yochai. 2006. The Wealth of Networks. New Haven, CT: Yale University Press.

Bhaskar, Roy. 1993. Dialectic: The Pulse of Freedom. London: Verso.

Bourdieu, Pierre. 1986. Distinction: A Social Critique of the Judgement of Taste. New York: Routledge.

\footnotetext{
43 "Wenn es um Gas, Elektrizität oder Wasser geht, ist der Staat verpflichtet, die Versorgung der Bevölkerung mit Energie sicherzustellen. Sollte er dazu nicht ebenso verpflichtet sein, wenn es um jene Art von 'Energie' geht, ohne deren Zufluss Störungen auftreten, die den demokratischen Staat selbst beschädigen? Es ist kein'Systemfehler', wenn der Staat versucht, das öffentliche Gut der Qualitätspresse im Einzelfall zu schützen" (Habermas 2008, 136f).
} 
Brevini, Benedetta. 2013. Public service broadcasting online. A comparative European policy study of PSB 2.0. Basingstoke: Palgrave Macmillan.

Burgess, Jean and Joshua Green. 2009. YouTube. Cambridge: Polity Press.

Calhoun, Craig. 1992. Introduction: Habermas and the Public Sphere. In Habermas and the Public Sphere, ed. Craig Calhoun, 1-48. Cambridge, MA: MIT Press.

Caporaso, James A. and David P. Levine. 1992. Theories of Political Economy. Cambridge: Cambridge University Press.

Castells, Manuel. 2009. Communication Power. Oxford: Oxford University Press.

Castells, Manuel. 2012. Networks of Outrage and Hope: Social Movements in the Internet Age. Cambridge: Polity Press.

Collins, Richard. 2010. From Public Service Broadcasting to Public Service Communication. In RIPE@2009: The Public in Public Service Media, ed. Gregory Ferrell Lowe, 53-69. Gothenburg: Nordicom.

Collins, Richard. 2011. Public Value, the BBC and Humpty Dumpty Words. In Exporting the Public Value Test. The Regulation of Public Broadcasters' New media Services Across Europe, ed. Karen Donders and Hallvard Moe, 29-37. Gothenburg: Nordicom.

Committee of Ministers. 2007. Recommendation CM/Rec(2007)3 of the Committee of Ministers to Member States on the Remit of Public Service Media in the Information Society. https://wcd.coe.int/ViewDoc.jsp?id=1089759 (accessed on December 15, 2013)

Couldry, Nick. 2010. Why Voice Matters. Culture and Politics after Neoliberalism. London: Sage.

Curran, James. 1991. Rethinking the Media as a Public Sphere. In Communication and Citizenship. Journalism and the Public Sphere, ed. Peter Dahlgren and Colin Sparks, 27-57. London: Routledge.

Curran, James and Jean Seaton. 2010. Power Without Responsibility. Press, Broadcasting and the Internet in Britain. London: Routledge. $7^{\text {th }}$ edition.

Dahlgren, Peter. 1995. Television and the Public Sphere. Citizenship, Democracy and the Media. London: Sage.

Donders, Karen. 2011. The Public Value Test. A Reasoned Response or Panic Reaction? In Exporting the Public Value Test. The Regulation of Public Broadcasters' New Media Services Across Europe, ed. Karen Donders and Hallvard Moe, 29-37. Gothenburg: Nordicom.

Eley, Geoff. 1992. Nations, Public and Political Cultures. Placing Habermas in the Nineteenth Century. In Habermas and the Public Sphere, ed. Craig Calhoun, 289-339. Cambridge, MA: MIT Press.

European Commission. 2009. Communication from the Commission on the Application of State Aid Rules to Public Service Broadcasting. http://eurlex.europa.eu/LexUriServ/LexUriServ.do?uri=CELEX:52009XC1027\%2801\%29:EN:NOT

Fraser, Nancy. 1992. Rethinking the Public Sphere. In Habermas and the Public Sphere, ed. Craig Calhoun, 109-142. Cambridge, MA: MIT Press.

Fuchs, Christian. 2003a. Some Implications of Pierre Bourdieu's Works for a Theory of Social SelfOrganization. European Journal of Social Theory, 6 (4): 387-408.

Fuchs, Christian. 2003b. Structuration Theory and Self-Organization. Systemic Practice and Action Research, 16 (4): 133-167.

Fuchs, Christian. 2008. Internet and Society. Social Theory in the Information Age. New York: Routledge.

Fuchs, Christian. 2010. Alternative Media as Critical Media. European Journal of Social Theory 13 (2): 173-192.

Fuchs, Christian. 2011. Towards an Alternative Concept of Privacy. Journal of Information, Communication and Ethics in Society 9 (4): 220-237.

Fuchs, Christian. 2013. The Anonymous Movement in the Context of Liberalism and Socialism. Interface: A Journal for and about Social Movements 5 (2): 345-376.

Fuchs, Christian. 2014a. Digital Labour and Karl Marx. New York: Routledge.

Fuchs, Christian. 2014b. OccupyMedia! The Occupy Movement and Social Media in Crisis Capitalism. Winchester: Zero Books.

Fuchs, Christian. 2014c. Social Media. A Critical Introduction. London: Sage.

Fuchs, Christian and Daniel Trottier. 2013. The Internet as Surveilled Workplayplace and Factory. In European Data Protection. Coming of Age, edited by Serge Gutwirth, Ronald Leenes, Paul de Hert and Yves Poullet, 33-57. Dordrecht: Springer.

Furhoff, Lars. 1973. Some Reflections on Newspaper Concentration. Scandinavian Economic History Review 21 (1): 1-27. 
Garnham, Nicholas. 1990. Capitalism and Communication. Global Culture and the Economics of Information. London: Sage.

Garnham, Nicholas. 1992. The Media and the Public Sphere. In Habermas and the Public Sphere, ed. Craig Calhoun, 359-376. Cambridge, MA: MIT Press.

Ghonim, Wael. 2012. Revolution 2.0. The Power of the People Is Greater Than the People in Power. New York: Houghton Mifflin Harcourt.

Giddens, Anthony. 1984. The Constitution of Society. Outline of the Theory of Structuration. Cambridge: Polity Press.

Goodwin, Peter. 2012. High Noon. The BBC Meets "the West's Most Daring Dovernment". In RIPE@2011: Regaining the Initiative for Public Service Media, ed. Gregory Ferrell Lowe and Jeanette Steemers, 63-76. Gothenburg: Nordicom.

Habermas, Jürgen. 1984. The Theory of Communicative action. Volume 1. Boston, MA: Beacon Press.

Habermas, Jürgen. 1987. The Theory of Communicative action. Volume 2. Boston, MA: Beacon Press.

Habermas, Jürgen. 1989. The Public Sphere: An Encyclopedia Article. In Critical theory and Society. A Reader, ed. Stephen E. Bronner and Douglas Kellner, 136-142. New York: Routledge.

Habermas, Jürgen. 1991. The Structural Transformation of the Public Sphere. An Inquiry into a Category of Bourgeois Society. Cambridge, MA: MIT Press.

Habermas, Jürgen. 1992. Further Reflections on the Public Sphere and Concluding Remarks In Habermas and the Public Sphere, ed. Craig Calhoun, 421-479. Cambridge, MA: MIT Press.

Habermas, Jürgen. 1996. Between Facts and Norms. Contributions to a Discourse Theory of Law and Democracy. Cambridge, MA: MIT Press.

Habermas, Jürgen. 2006. Political Communication in Media Society: Does Democracy Still Enjoy an Epistemic Dimension? The Impact of Normative Theory on Empirical Research. Communication Theory 16 (4): 411-426.

Habermas, Jürgen. 2008. Ach, Europa. Frankfurt am Main: Suhrkamp.

Habermas, Jürgen. 2011. Zur Verfassung Europas. Ein Essay. Frankfurt am Main: Suhrkamp.

Hayes, Ben. 2012. The Surveillance-Industrial Complex. In Routledge Handbook of Surveillance Studies, ed. Kirstie Ball, Kevin D. Haggerty and David Lyon, 167-175. Abingdon: Routledge.

Horkheimer, Max and Theodor W. Adorno. 2002. Dialectic of Enlightenment. Stanford, CA: Stanford University Press.

Hume, David. 1739. A Treatise of Human Nature. Oxford: Oxford University Press.

losifides, Petros. 2010. Pluralism and Funding of Public Service Broadcasting in Europe. In Reinventing Public Service Communication. European Broadcasters and Beyond, ed. Petros losifides, 9-22. Basingstoke: Palgrave Macmillan.

Jakubowicz, Karol. 2007. Public Service Broadcasting in the $21^{\text {st }}$ century. In From Public Service Broadcasting to Public Service Media. RIPE@2007, ed. Gregory Ferrell Lowe and Jo Bardoel, 2949. Gothenburg: Nordicom.

Jameson, Frederic. 1988. On Negt and Kluge. October 46: 151-177.

Jhally, Sut. 1990. The Codes of Advertising. Fetishism and the Political Economy of Meaning in the Consumer Society. New York: Routledge.

Jin, Dal Yong. 2013. The Construction of Platform Imperialism in the Globalization Era. tripleC: Communication, Capitalism \& Critique 11 (1): 145-172.

Kant, Immanuel. 1784. An Answer to the Question: What is Enlightenment? In The Idea of the Public Sphere. A Reader, ed. Jostein Gripsrud, Hallvard Moe, Anders Molander and Graham Murdock, 38. Lanham, MD: Rowman \& Littlefield.

Kant, Immanuel. 1785. Groundworks of the Metaphysics of Morals. A German-English Edition. Cambridge: Cambridge University Press.

Kitching, John and David Smallbone. 2012. UK Freelance Workforce, 2011. Kingston upon Thames: Kingston University.

Kovisto, Juha and Esa Valiverronen. 1996. The Resurgence of the Critical Theories of Public Sphere. Journal of Communication Inquiry 20 (2): 18-36.

Kreilinger, Verena. 2014. Research Design \& Data Analysis, Presentation, and Interpretation: Part Two. The Internet \& Surveillance Research Paper Series \#14. Vienna: UTI Research Group.

Locke, John. 1690. Two treatises of government. Cambridge: Cambridge University Press.

Luhmann, Niklas. 1995. Social Systems. Stanford: Stanford University Press. 
Lunt, Peter and Sonia Livingstone. 2013. Media Studies' Fascination with the Concept of the Public Sphere: Critical Reflections and Emerging Debates. Media, Culture \& Society 35 (1): 87-96.

Lunt, Peter, Sonia Livingstone and Benedetta Brevini. 2012. Changing Regimes of Regulation. Implications for Public Service Broadcasting. In RIPE@2011: Regaining the Initiative for Public Service Media, ed. Gregory Ferrell Lowe and Jeanette Steemers, 113-128. Gothenburg: Nordicom.

Lyons, Glenn, Juliet Jain, Yusak Susilo and Stephen Atkins. 2013. Comparing Rail Passengers' Travel Time Use in Great Britain between 2004 and 2010. Mobilities 8 (4): 560-579.

Macpherson, Crawford B. 1962. The Political Theory of Possessive Individualism. Oxford: Oxford University Press.

Marx, Karl. 1843. On the Jewish Question. In Writings of the Young Marx on Philosophy and Society, 216-248. Indianapolis, IN: Hackett.

Marx, Karl. 1842. Freedom in General. http://www.marxists.org/archive/marx/works/1842/freepress/ch06.htm

Marx, Karl and Friedrich Engels. 1845. The German Ideology. Amherst, NY: Prometheus.

McGuigan, Jim. 1998. What Price the Public Sphere? In Electronic Empires. Global Media and Local Resistances, ed. Daya Kishan Thussu, 108-124. London: Hodder Arnold.

Mill, John Stuart. 1848. Principles of Political Economy. And: Chapters on Socialism. Oxford: Oxford University Press.

Mill, John Stuart. 1859. On Liberty. In On Liberty and Other Essays, 5-128. Oxford: Oxford University Press.

Mills, C. Wright. 1956. The Power Elite. Oxford: Oxford University Press.

Mouffe, Chantal. 1999. Deliberative Democracy or Agonistic Pluralism? Social Research 66 (3): 745758.

Murdock, 2005. Building the Digital Commons: Public Broadcasting in the Age of the Internet. In Cultural Dilemmas of Public Service Broadcasting, ed. by Per Jauert and Gregory F. Lowe, 213-230. Gothenburg: Nordicom.

Murdock, Graham. 2011. Political Economies as Moral Economies. Commodities, Gifts, and Public Goods. In The Handbook of the Political Economy of Communications, eds. Janet Wasko, Graham Murdock and Helena Sousa, 13-40. Chicester: Wiley-Blackwell.

Murdock, Graham. 2014. Commodities and Commons. In The Audience Commodity in a Digital Age, ed. Lee McGuigan and Vincent Manzerolle, 229-244. New York: Peter Lang.

Negt, Oskar and Alexander Kluge. 1993. Public Sphere and Experience. Toward an Analysis of the Bourgeois and Proletarian Public Sphere. Minneapolis, MN: University of Minnesota Press.

Ofcom. 2007. Methodology for Market Impact Assessments of BBC services. http://stakeholders.ofcom.org.uk/binaries/research/tv-research/bbc-mias/bbc-mia-meth.pdf (accessed December 8, 2013).

Papacharissi, Zizi. 2009. The Virtual Sphere 2.0. The Internet, the Public Shpere, and Beyond. In Routledge Handbook of Internet Politics, eds. Andrew Chadwick and Philip N. Howard, 230-245. New York: Routledge.

Roberts, John Michael and Nick Crossley. 2004. Introduction. In After Habermas: New Perspectives on the Public Sphere, ed. Nick Crossley and John Michael Roberts, 1-27. Malden, MA: Blackwell.

Sandoval, Marisol and Christian Fuchs. 2010. Towards a Critical Theory of Alternative <edia. Telematics and Informatics 27 (2): 141-150.

Scannell, Paddy. 1989. Public Service and Modern Public Life. Media, Culture and Society 11 (2): 135-166.

Scholz, Trebor, ed. 2013. Digital Labor. The Internet as Playground and Factory. New York: Routledge.

Smith, Adam. 1790. The Theory of Moral Sentiments. London: Penguin.

Smythe, Dallas W. 1954. Reality as Presented by Television. In Counterclockwise. Perspectives on Communication, 61-74. Boulder, CO: Westview Press.

Smythe, Dallas W. 1977. Communications: Blindspot of Western Marxism. Canadian Journal of Political and Social Theory 1 (3): 1-27.

Sparks, Colin. 1998. Is There a Global Public Sphere? In Electronic Empires. Global Media and Local Resistances, ed. Daya Kishan Thussu, 91-107. London: Hodder Arnold.

Splichal, Slavko. 2007. Does History Matter? Grasping the Idea of Public Service at its Roots. In From Public Service Broadcasting to Public Service Media. RIPE@2007, ed. Gregory Ferrell Lowe and Jo Bardoel, 237-256. Gothenburg: Nordicom. 
Steuart, James. 1767. An Inquiry into the Principles of Political Economy.

http://www.marxists.org/reference/subject/economics/steuart/index.htm

Thale, Mary. 1989. London Debating Societies in the 1790s. The Historical Journal 32 (1): 58-86.

Thale, Mary. 1995. Women in London Debating Societies in 1780. Gender \& History 7 (1): 5-24.

Thompson, Edward B. 1963. The Making of the English Working Class. New York: Vintage Books.

Turow, Joseph and Matthew McAllister, eds. 2009. The Advertising and Consumer Culture Reader. New York: Routledge.

Wang, Di. 2008. The Idle and the Busy. Teahouses and Public Life in Early Twentieth-Century Chengdu. Journal of Urban History 26 (4): 411-437.

Williams, Raymond. 1977. Marxism and Literature. Oxford: Oxford University Press.

Williams, Raymond. 1989. What I Came to Say. London: Hutchinson Radius.

Williams, Raymond. 1990. Television. London: Routledge. Second edition.

\section{About the Author}

\section{Christian Fuchs}

Is professor of social media at the University of Westminster's Communication and Media Research Institute and the Centre for Social Media Research. He is editor of tripleC: Communication, Capitalism \& Critique and author of many publications, including the books Social Media: A Critical Introduction (Sage 2014), Digital Labour and Karl Marx (Routledge 2014), OccupyMedia! The Occupy Movement and Social Media in Crisis Capitalism (Zero Books 2014), Foundations of Critical Media and Information Studies (Routledge 2011), Internet and Society: Social Theory in the Information Age (Routledge 2008). He recently edited together with Marisol Sandoval the collected volume Critique, Social Media and the Information Society (Routledge 2014). 